NBER WORKING PAPER SERIES

\title{
DO AFTER-TAX RETURNS AFFECT MUTUAL FUND INFLOWS?
}

\author{
Daniel Bergstresser \\ James Poterba \\ Working Paper 7595 \\ http://www.nber.org/papers/w7595 \\ NATIONAL BUREAU OF ECONOMIC RESEARCH \\ 1050 Massachusetts Avenue \\ Cambridge, MA 02138 \\ March 2000
}

\begin{abstract}
We are grateful to Svetla Tzenova for outstanding research assistance, and to the Momingstar Corporation, Mark Carhart, and Ken French for providing us with data. We also thank David Cutler, Jonathan Gruber, Martin Gruber, John Rekenthaler, Julio Rotemberg, Richard Ruback, John Shoven, Steve Zeldes, seminar participants at the NBER Summer Institute and the Harvard Business School, and especially Joel Dickson for helpful comments. We are grateful to the National Institute of Aging, the National Science Foundation, and the Smith-Richardson Foundation for research support. The views expressed herein are those of the authors and are not necessarily those of the National Bureau of Economic Research.
\end{abstract}

(C) 2000 by Daniel Bergstresser and James Poterba. All rights reserved. Short sections of text, not to exceed two paragraphs, may be quoted without explicit permission provided that full credit, including $(\mathcal{C}$ notice, is given to the source. 
Do After-Tax Returns Affect Mutual Fund Inflows?

Daniel Bergstresser and James Poterba

NBER Working Paper No. 7595

March 2000

JEL No. G1 1, H24, G23

\section{ABSTRACT}

This paper explores the relationship between the after-tax returns that taxable investors earn on equity mutual funds and the subsequent cash inflows to these funds. Previous studies have documented that funds with high pretax returns attract greater inflows. This paper investigates the relative predictive power of pre-tax and after-tax returns for explaining annual fund inflows. The empirical results, based on a large sample of equity mutual funds over the period 1993-1998, suggest that after-tax returns have more explanatory power than pretax returns in explaining inflows. In addition, funds with large "overhangs" of unrealized capital gains experience smaller inflows, all else equal, than funds without such unrealized gains. By disaggregating net fund inflows into gross inflows and gross redemptions, the paper also provides some insight on how after-tax returns and prospective capital gain realizations affect investor behavior.

Daniel Bergstresser

Department of Economics

MIT

50 Memorial Drive

Cambridge, MA 02142-1347

dberg@mit.edu
James Poterba

Department of Economics, E52-350

MIT

50 Memorial Drive

Cambridge, MA 02142-1347

and NBER

poterba@mit.edu 
Mutual funds in the United States are taxed under a specialized set of rules. First, they are required to "pass through" dividends and capital gain realizations to their investors. This restricts the fund investor's ability to exploit tax-timing strategies of the type discussed by Stiglitz (1983), Constantinides (1984), and Dammon and Spatt (1996). Dickson and Shoven (1995) claim that in the early 1990s, some mutual fund managers pursued realization strategies that imposed unnecessarily large tax burdens on shareholders. One example would be choosing to sell the lowest-basis tranche of a security in their portfolio, thereby imposing a larger-than-necessary capital gains tax burden on their taxable investors. The Congressional Budget Office (1999) estimates that mutual fund capital gain distributions, which exceeded $\$ 180$ billion in 1997 , contributed roughly $\$ 15$ billion to federal capital gains tax revenues for that year.

Second, capital gain and dividend realizations are allocated equally across mutual fund shares, regardless of when the shares were created. New fund investors are allocated the same share of capital gain realizations as old investors, even though their shares in the fund may have been created after the gains being realized accrued to the fund. Investors who purchase shares in funds that have accrued but unrealized capital gains therefore face the prospect of distributions of realized capital gains during the period for which they hold the fund. Accrued but unrealized gains are often called a "capital gain overhang." Barclay, Pearson, and Weisbach (1998) present evidence that funds with larger overhangs have lower net inflows than other funds, and Warther (1998) develops a theoretical model that is designed to explain when mutual funds might choose to build up an overhang of unrealized gains.

The tax issues surrounding mutual fund investment have become increasingly significant as mutual funds have become a more important channel for individual equity ownership. Data from the 1998 Survey of Consumer Finances reported in Kennickell, Starr-McCluer, and Surette (2000) show that 16.5 percent of families now own mutual funds, excluding ownership of such funds through retirement accounts. This compares with 19.2 percent of families with direct ownership of corporate stock. Many other families own mutual funds through retirement accounts. The tax implications of mutual fund 
ownership through retirement plans are different from the implications of direct fund ownership, since realized gains are not taxed until assets are withdrawn from the retirement account, and then they are taxed as ordinary income.

The current study evaluates the impact of personal taxation on the returns earned by mutual fund investors. It then considers how the tax burden on different funds affects investor purchases and redemptions of shares in these funds. There is a large previous literature on the relationship between fund performance and subsequent net inflows, including work by Ippolito (1992), Hendricks, Patel, and Zeckhauser (1994), Chevalier and Ellison (1996), Sirri and Tufano (1997), and Warther (1997). This literature uniformly finds that at the individual fund level, net inflows are positively related to past performance. Because there is some persistence in fund performance, Gruber (1996) finds that an inflowweighted-average of mutual fund returns generates a higher average return than a fund-weighted return: The precise explanation of persistence in fund returns, and the implications of such persistence for investor behavior, is still an open issue. Carhart (1997) shows that persistence in fund expenses and medium-term persistence in underlying asset returns, rather than persistence in stock-picking ability, explain most of the persistence in fund retums that has been identified in previous studies.

Virtually all of the existing studies of returns and fund inflows focus on pretax returns. In the current paper, we extend this work in three ways. First, we consider the relationship between net inflows and both realized and potential individual income tax burdens. We find that funds that deliver returns that are more heavily taxed, i.e. come in the form of dividends or realized capital gains, have lower subsequent inflows than funds with similar pretax returns that are not so heavily taxed. After-tax return measures outperform pretax retums in explaining net inflows.

Second, we explore the factors that explain the cross-sectional variation in the tax burdens that domestic equity mutual funds impose on their investors. We consider the impact of fund tumover, the tenure of the management team, investment style, and other factors in contributing to the divergence between pretax and after-tax return. Tumover has a large effect on capital gain realizations, and new fund managers tend to impose large capital gains tax liabilities on investors by realizing accrued capital gains. 
We also confirm Barclay, Pearson, and Weisbach's (1998) result that funds with larger stocks of unrealized capital gains have smaller net inflows, conditional on their past return performance.

Finally, we move beyond the study of net fund inflows to explore the relationship between fund performance, gross fund inflows, and gross redemptions. Previous studies have focused on net fund flows because data on gross flows is not as readily available as data on net flows. We collect new data from SEC filings that describe gross inflows and gross outflows, and we use these data to evaluate how investors adjust their investment decisions in response to differences in after-tax returns and prospective capital gains tax liability.

The paper is divided into six sections. The first describes how we construct risk-adjusted and taxadjusted mutual fund returns. Mutual fund investors are heterogeneous, and we are forced to make some simplifying assumptions about the tax burdens on fund investors. This section also describes our database of fund returns, and reports summary statistics on the level and persistence of pretax and aftertax returns of a large sample of equity mutual funds in the 1990s. Section two explores the determinants of the tax burdens on the returns to different equity mutual funds. We investigate how various fund characteristics are correlated with 'tax efficiency,' and find several aspects of fund behavior that have substantial predictive power in explaining investor tax burdens.

The third section describes the data set that we use to measure annual net inflows to U.S. equity mutual funds, and it presents summary information on net flows during the sample period that we consider. In section four, we report our basic findings on the relationship between fund returns, potential capital gains distributions, and fund net inflows. We compare the relative predictive power of pretax and after-tax returns in a range of regression models for fund inflows, controlling for a variety of other factors that may affect investor behavior. The results support the notion that tax burdens affect fund inflows, and the findings are robust with respect to the inclusion of many control variables. Section five presents our analysis of how gross inflows and gross outflows vary with past performance. We describe the data that we have collected on gross flows for a large sample of funds, and we study whether gross redemptions, or gross inflows, or both, are affected by fund tax burdens and unrealized capital gains. We 
find that funds with substantial capital gains "tax overhang" experience both lower inflows, as taxsensitive investors avoid such funds, and lower outflows, as investors are reluctant to sell these funds and realize the associated capital gains. A brief conclusion suggests several directions for future work.

\section{Measuring Pretax and After-Tax Returns on Mutual Funds}

Mutual funds generate three types of taxable returns for their investors. These are dividends, which are passed through to the investor and taxed as ordinary income, short-term realized capital gains, which are also taxed as ordinary income, and long-term capital gain realizations, which are taxed at the prevailing long-term capital gains tax rate. Even if an investor has held a mutual fund for less than the holding period that is required for long-term capital gains tax status for other assets, a mutual fund's longterm capital gain realizations are still taxed as long-term gains. (In 1997 and 1998, it was also possible for mutual funds to generate a fourth type of taxable income, 'intermediate term' capital gains, that were taxed at a rate ( 28 percent) between the ordinary income tax rate and the long-term gains rate.) In addition to these taxable returns, equity mutual funds may also generate "untaxed" returns in the form of unrealized capital gains. The tax burden on such returns is a function of investor behavior rather than fund manager behavior. Provided the investor does not sell his shares in the fund, there is no tax due on unrealized gains.

Most discussions of mutual fund returns, and most academic studies of fund behavior and return performance, focus on pretax returns. Such returns are just the sum of the four return components described above. Recently, however, there has been increased attention to the after-tax returns on different mutual funds. Dickson and Shoven (1995) and construct after-tax measures of fund returns for hypothetical investors, and they show that the relative standing of various funds in rankings of fund returns can be quite sensitive to the choice between pretax and after-tax returns. Morningstar, a leading mutual fund information service, has recently started to publish post-tax return measures in its fund performance database. In 1999, the Vanguard mutual fund family began to report returns to shareholders on both a pre-tax and after-tax basis. 
Despite the interest in after-tax returns, there is no consensus on how to measure such returns. There are important differences across investors in their tax status, so it is not possible to create a "one size fits all" measure of after-tax fund performance. We follow Dickson and Shoven (1995) in constructing after-tax returns for hypothetical upper-income investors. Because most mutual fund investors face marginal tax rates on dividend and interest income, and on short-term capital gains, of between 28 and 39.6 percent, and long-term capital gains tax rates of 20 percent, the degree of tax rate heterogeneity is limited. Ignoring taxes completely is likely to result in a larger mis-statement of after-tax returns than adjusting returns with imprecise tax rates.

To formalize our tax calculations for mutual fund returns, we define a fund's total pretax return as

$$
R_{p}=d+g_{s}+g_{1}+u
$$

where $\mathrm{d}$ denotes dividend payout as a fraction of the beginning-of-year net asset value, $\mathrm{g}_{\mathrm{s}}$ denotes realized short-term capital gains, $\mathbf{g}_{1}$ denotes realized long-term gains, and $\mathbf{u}$ denotes unrealized capital gains.

Consider a taxable investor who faces a tax rate of $\tau_{\mathrm{d}}$ on dividends and short-term realized gains and a rate of $\tau_{\mathrm{cg}}$ on realized long-term capital gains. Assume that the effective accrual tax rate on unrealized capital gains, which as Poterba (1999) explains is the present discounted value of the future taxes that will be due on these gains, is $\tau_{\text {uč }}$. We define the fund's one-year 'buy and hold' after-tax return as

$$
\mathrm{R}_{\mathrm{a}}=\left(1-\tau_{\mathrm{d}}\right) *\left(\mathrm{~d}+\mathrm{g}_{\mathrm{s}}\right)+\left(1-\tau_{\mathrm{cg}}\right) * \mathrm{~g}_{\mathrm{l}}+\left(1-\tau_{\mathrm{ucg}}\right) * \mathrm{u} .
$$

We assume an effective tax rate of $\tau_{\mathrm{ucg}}<\tau_{\mathrm{cg}}$ on gains that are not distributed during the current calendar year. If the mutual fund never realizes these gains, and if the investor holds his shares until he dies, so that the resulting capital gains tax liability is extinguished through basis step-up at death, then effective tax rate on these undistributed gains would be zero. In practice, it is likely both that the investor will sell mutual fund shares before death, and that the mutual fund manager will realize at least part of the gain in future years. The effective tax rate on undistributed accruing gains therefore depends on the fund manager's realization strategy and the investor's investment horizon. It also depends on the rate of return at which the investor discounts future tax liabilities. 
In most of our empirical work, we assume a value of 0.10 for $\tau_{\mathrm{ucg}}$. This is half the statutory tax rate on realized long-term gains, and it is broadly consistent with effective tax rate calculations using a range of plausible values for realization rates and discount rates. Our empirical results are quite robust to alternative assumptions about this tax parameter, including an assumption that it equals zero. The difficulty of measuring the tax burden on unrealized gains is an inherent limitation of our focus on annual fund returns. Because the after-tax return on a long-term investment can only be measured precisely over a long holding period, there is necessarily some approximation involved in assigning one-period tax burdens to fund investments.

The problem of approximating future tax burdens would vanish if we assumed that the mutual fund investor sold his shares at the end of the calendar year. In this case, the after-tax return would be

$$
\mathrm{R}_{\mathrm{a}}{ }^{\prime}=\left(1-\tau_{\mathrm{d}}\right) *\left(\mathrm{~d}+\mathrm{g}_{\mathrm{s}}\right)+\left(1-\tau_{\mathrm{cg}}\right) *\left(\mathrm{~g}_{1}+\mathrm{u}\right)
$$

In this case all unrealized gains or losses from the fund's investments in the current year are taxable in the current year. The option to sell mutual fund shares provides investors with an important protection against purchasing a mutual fund and facing a large capital gain distribution. If the fund distributes gains that were accrued before the investor purchased the fund, this will reduce the net asset value of the fund's shares. In this case the investor can sell the shares, realize a capital loss on the mutual fund shares, and use this loss to offset the gain that was passed through from the fund. This realization strategy is often ignored in discussions of the potential tax burdens associated with capital gain 'overhangs.'

We use the difference between the pretax return in (1) and the after-tax return in (2) to measure the fund's tax burden. We could scale this by the fund's pretax return, thereby constructing an 'effective tax rate,' but we do not follow this approach because it runs into difficulty when a fund experiences negative returns. Our measure of the fund's tax burden is therefore

$$
\mathrm{T}=\tau_{\mathrm{d}} *\left(\mathrm{~d}+\mathrm{g}_{\mathrm{s}}\right)+\tau_{\mathrm{cg}} * \mathrm{~g}_{1}+\tau_{\mathrm{ucg}} * \mathrm{u} .
$$

To construct this measure of a fund's tax burden, we need data on both long-term and short-term capital gain realizations. Morningstar has provided us with historical data on the disaggregated capital 
gain components for the funds that survived to January 1999. However, for mutual funds that were traded earlier in the 1990s, but that disappeared due to merger or liquidation prior to January 1999 , we have only been able to obtain data on total capital gain distributions. We thus face a choice between studying a sample of funds that is likely to be subject to survivorship bias but for which we have accurate measures of tax burdens, or studying a sample of funds with very little survivorship bias but with inaccurate tax burden data. Previous work, cited in Carpenter and Lynch (1999), suggests that funds with poor returns are most likely to be merged or liquidated and that this may induce biases in studying the persistence of fund returns or inflows. Most of our analysis therefore uses data on all funds that were traded during our sample period, but does not distinguish between long-term and short-term capital gain realizations. This imparts some measurement error to our analysis of tax burdens.

When we do not know the disaggregate composition of realized gains, we assume that all gains are long-term. We therefore define after-tax returns as

$$
\mathrm{R}^{\prime \prime}{ }_{\mathrm{a}}=\left(1-\tau_{\mathrm{d}}\right) * \mathrm{~d}+\left(1-\tau_{\mathrm{eg}}\right) *\left(\mathrm{~g}_{\mathrm{l}}+\mathrm{g}_{\mathrm{s}}\right)+\left(1-\tau_{\mathrm{ucg}}\right)^{* \mathrm{u}}
$$

and we measure the tax burden as

$$
\mathrm{T}^{\prime \prime}=\tau_{\mathrm{d}} * \mathrm{~d}+\tau_{\mathrm{cg}} *\left(\mathrm{~g}_{\mathrm{l}}+\mathrm{g}_{\mathrm{s}}\right)+\tau_{\mathrm{ucg}} * \mathrm{u}
$$

To assess the magnitude and direction of any bias that results from aggregating short-term and long-term gain realizations, we compare our basic findings for one year, 1999, using measures (2) and (3) as well as (2') and (3') to define after-tax returns. Fortunately, the results of this comparison suggest that using a noisy tax measure may not have a large impact on our results.

A critical question in defining the after-tax return concerns the appropriate tax rates to use in evaluating (2) and (3). It is difficult to know the precise tax rates facing mutual fund investors. Information from tax returns, which can be used to compute 'weighted average' tax rates on interest or dividend income such as those used in Poterba (1998), does not identify the income from mutual funds as opposed to other investments. Other sources of information on asset ownership, such as the Survey of Consumer Finances (SCF), provide only sketchy information about household attributes that may affect 
marginal tax rates. Poterba and Samwick (1999) attempt to impute marginal tax rates to households in the SCF, and they discuss the potential pitfalls of such an approach. One of the most important problems is that it is not possible to identify the characteristics of the particular mutual funds that each household owns. If high tax rate households tend to invest in mutual funds that are more tax efficient than the funds held by lower tax rate households, calculations based simply on mutual fund ownership may mis-state actual tax burdens.

In our estimates of the tax burden on mutual fund returns, we assume that dividend income and short-term capital gain realizations are taxed at the marginal personal income tax rate of 31 percent. This is equivalent to assuming that the 'marginal investor' receiving income from mutual funds has 1998 taxable income of between $\$ 102,300$ and $\$ 155,950$. We further assume that all capital gains are long term and that they are taxed at the prevailing maximum long-term capital gains tax rate, which is 20 percent in 1998. Our calculations assume the same tax rates in computing the after-tax returns for all funds. This ignores the possibility that investors form clienteles, with taxable investors purchasing one set of funds, and tax-exempt investors purchasing another set. We do not currently have the data on fund ownership that would be needed to investigate the importance of clientele formation.

Table 1 presents summary information on the direct ownership of mutual funds from the 1995 SCF. Of the 12.2 million households that owned taxable mutual funds in 1995 , more than three-quarters had annual income of less than $\$ 100,000$. These households owned 54 percent of all taxable mutual fund assets. The table also shows that while families with incomes of more than $\$ 250,000$ represent only 2.9 percent of mutual fund investors, they hold 18.5 percent of the assets in taxable mutual funds. These statistics are generally supportive of our use of marginal tax rates that correspond to households in the upper part, but not the top, of the income distribution.

Table 1 also shows that there are substantial differences across income categories in the probability that a household owns any taxable mutual funds. For households with incomes of less than $\$ 50,000$, this probability is 7.7 percent, rising to 40.1 percent for households with incomes between $\$ 150,000$ and $\$ 250,000$. The probability of owning a taxable mutual fund is lower for those in the highest 
income category ( 38.8 percent for those with incomes of $\$ 250,000$ and above) than for those in the income category just below this level. This pattern stands in contrast to the income-specific ownership patterns for mutual funds held through retirement accounts and for direct stock ownership, both of which show rising ownership probabilities across the income spectrum.

\subsection{Data on Mutual Fund Returns}

We restrict our analysis to U.S. domestic equity mutual funds, and we obtain data on fund returns from the six January releases of the Morningstar mutual fund database published between 1994 and 1999. Because funds that disappear through merger or liquidation are removed from subsequent editions of the Morningstar database, using the end-of-sample data release for retrospective analysis of fund performance may result in survivorship biases. We avoid this problem, and also obtain additional data on historical values of fund characteristics such as load structure, manager tenure, and fund objective, by merging data from each of the six annual data releases.

Our data set mirrors the set of equity funds available to investors in each year between 1994 and 1999. We begin with the all equity funds in the various Morningstar data files, and we exclude any observations for which Morningstar does not report a ticker symbol, a net asset value, or a value for total fund assets at year-end. We further exclude funds that are identified as bond funds, hybrid funds, international funds, and specialty equity funds, and we limit our analysis to domestic equity funds that are open to new investment from retail customers. These exclusions yield a "potential data sample" of 10,789 fund-year observations, of which 2,984 are in 1998 . From this potential data sample, we exclude 3,482 fund-years corresponding to funds with less than three years of historical returns. This limits our sample to funds with established track records. We exclude an additional 36 fund-years in which measured net inflows exceed ten times beginning-of-period size, and five additional fund-years for which Morningstar did not report ratings or information on the median market capitalization of the stocks in the fund's portfolio. The net effect of these exclusions is to leave a sample with 5,866 fund-years of data, of which 1,607 are for 1998. The year-end 1998 market value of the funds in our sample was about $\$ 1.5$ trillion. 
The two most important sample restrictions that we impose are the exclusion of institutional equity funds, which held $\$ 182$ billion in assets at the end of 1998 , and the exclusion of funds that are closed to new investors. Funds that were closed in 1998, such as Fidelity Magellan, held $\$ 277$ billion in assets. Excluding international stock funds and specialty domestic funds are also substantial restrictions; foreign stock funds accounted for $\$ 176$ billion in assets at the end of 1998 .

\subsection{Summary Statistics on Pretax and After-tax Returns}

Table 2 presents summary statistics on the mean and median returns, and the components of returns, for our data sample. These statistics highlight the importance of tax factors in affecting returns to taxable investors. For the 1993-1998 period, the mean pretax return on equity mutual funds (shown in the upper panel of the table) is 17.1 percent per year, while the mean after-tax return is 14.1 percent. The sample period that we consider has been characterized by very favorable returns on the U.S. equity market in general, so our average returns are likely to be significantly higher than those that would be observed over longer sample periods.

Table 2 provides some insight on the reason for the difference between the pretax and after-tax return. Undistributed capital gains generate, on average, a 7.8 percent return for fund shareholders. Heavily taxed dividends average 1.0 percent, and capital gain distributions account for an average pretax return of 8.3 percent. Given our assumptions about the marginal tax rates of the representative mutual fund investor, these pretax returns generate a tax burden of 3.0 percent per year. If we assumed a lower tax burden on undistributed capital gains, the tax burden would be correspondingly lower. If we set this tax rate to zero, the tax burden would average 2.6 percent per year.

Our data confirm Dickson and Shoven's (1995) finding of significant heterogeneity in the tax liabilities associated with different mutual fund investments. The range in the tax burdens between the $75^{\text {th }}$ and $25^{\text {th }}$ percentile funds, when the ranking is by tax burdens, is 2.4 percentage points.

Table 3 presents summary statistics on pretax and after-tax returns for each of the years in our sample period. We show means that weight each mutual fund equally, as well as means that weight funds by their total assets under management. Asset-weighted summary statistics describe the return on the 
average dollar invested in equity mutual funds better than fund-weighted summary statistics. The first column of Table 3 shows the number of mutual funds in our sample for each year. The next two columns show year-by-year equal-weighted average pretax returns, and average tax burdens. The last two columns show analogous weighted average returns. The results show that returns on large funds have exceeded those on small funds. The asset-weighted mean pretax retum is 20.9 percent per year, compared with a mean return of 17.1 percent when funds are weighted equally. The average tax burden is 3.4 percent on an asset-weighted basis, and 3.0 percent on an asset-weighted basis.

The statistics on interquartile ranges in Table 2 suggest significant variation in both returns and tax burdens across funds. Tables 4 and 5 illustrate this heterogeneity in a more immediate way. Table 4 reports the pretax return, tax burden, after-tax return, and unrealized capital gains as a share of assets for the twenty largest funds in our sample for calendar year 1998. Table 5 reports similar statistics for the twenty largest S\&P 500 index funds in our sample. While the twenty largest equity funds differ in both characteristics and clientele, the S\&P 500 index funds share important similarities.

The data in Table 4 show a wide range of tax burdens for different funds. An investor facing the tax rates that we assume, and holding the American Century-20 $0^{\text {th }}$ Century Ultra Fund in 1998 , faced a tax burden of 4.5 percentage points. The same investor holding the Fidelity Blue-Chip Growth fund would have faced a tax burden of 4.0 percent on a comparable pre-tax return, while by holding the Vanguard Index 500 fund, the investor would have faced a tax burden of 3.2 percentage points. (Note that these "tax burdens" include our estimates of the future taxes that will be due on currently unrealized capital gains.)

Table 5 shows striking differences in the after-tax performance of different S\&P 500 index funds. This comparison is suggestive of substantial heterogeneity across equity funds more generally, because all of the funds in Table 5 have ostensibly similar investment objectives. The Vanguard Index 500 fund turns in the best after-tax performance. While a number of other funds have after-tax returns that are bunched within 20 basis points of the Vanguard Index 500 , several underperform by more than 100 basis points, and two underperform by more than 350 basis points. These differences in part reflect the fact that different index funds have different requirements on the share of fund assets that must be held in stocks 
that are included in the index. Much of the variation in the after-tax returns across "index funds" reflects variation in pretax returns, but there also appear to be important differences in tax management styles across these funds.

\section{$\underline{1.3 \text { Risk Adjusting Returns }}$}

Our discussion so far has considered returns on different mutual funds without any recognition of potential differences in fund risk characteristics. Since our ultimate objective is to study how returns affect inflows, we need to allow for the differential riskiness of the investment strategies pursued by different funds. One could imagine a spurious relationship between past fund returns and current fund inflows that is driven solely by a relationship between both of these variables and a third factor, which is the fund's risk profile.

Previous researchers have related fund inflows to three different measures of risk-adjusted fund returns: the fund return relative to a market index $\left(\mathrm{A}^{\mathrm{m}}{ }_{\mathrm{it}}=\mathrm{R}_{\mathrm{it}}-\mathrm{R}^{\mathrm{m}}{ }_{\mathrm{t}}\right)$; the 'alpha' from a one-factor riskadjustment model $\left(A^{\prime}{ }_{i t}=R_{i t}-r_{t}-\beta^{m}{ }_{i t} *\left(R^{m}{ }_{t}-r_{t}\right)\right)$; and the alpha from a multifactor pricing model. Chevalier and Ellison's (1997) analysis of inflows uses the first measure, while Gruber's (1996) study uses alphas from one-factor and four-factor models. Gruber's (1996) four-factor return relationship includes the market return, a bond index return, and returns to portfolios designed to capture market capitalization and growth-value effects. Carhart's (1997) model is similar to Gruber's (1996), but it also includes a medium-term persistence factor ('momentum') discussed in Jegadeesh and Titman (1993).

In our empirical analysis, we present results using relative returns $\mathrm{A}^{\mathrm{m}}$ and one-factor risk adjusted returns $\mathrm{A}^{\prime}$. A previous version of this paper, using the set of funds which survived to January 1999 , reported results based on a five-factor alpha with market return, capitalization portfolio return, bond portfolio return, book-market portfolio return, and 'momentum' factor return. The results were very similar to what we report below, particularly with regard to the differential explanatory power of beforetax and after-tax returns. We focus our analysis on the simplest risk-adjustment strategy in part because the simplest relative return measure appears to be the strongest predictor of fund inflows. 
The alternative risk-adjustment strategies have a limited impact on the relative ranking of funds by after-tax performance. Funds with extreme relative returns $\left(\mathrm{A}^{\mathrm{m}}\right)$ also show extreme risk-adjusted returns $\left(A^{1}\right)$. Of the 586 fund-years in the bottom decile of relative returns, 455 ( 78 percent) were in the bottom decile of one-factor adjusted returns, and another 100 (17 percent) were in the next decile. An additional 18 fund-years ( 3 percent) were in the next two deciles of the return distribution. At the top of the return distribution, the overlap is also striking. Of the 586 fund years in the top decile of relative returns, 95 percent of the fund-years were in the top two deciles of risk-adjusted returns.

It is conceptually more difficult to define an after-tax risk-adjusted portfolio performance measure than to define a pre-tax measure. We use the estimated $\beta$ from a one-factor pricing model estimated using pre-tax returns, the income tax rate, and the dividend distributions from the S\&P 500 $\left(\mathrm{SP} 500_{\text {inc }}\right)$ to construct an after-tax one-factor risk-adjusted return measure:

$$
\mathrm{A}_{\mathrm{a}}{ }_{\text {it }}=\mathrm{R}_{\mathrm{a}, \mathrm{i}}-\left(1-\tau_{\mathrm{d}}\right) * \mathrm{r}_{\mathrm{i}}-\beta^{\mathrm{n} 1}{ }_{\mathrm{it}} *\left[\left(1-\tau_{\mathrm{d}}\right) * \mathrm{SP} 500_{\mathrm{inc}}+\left(1-\tau_{\mathrm{ucg}}\right) * \mathrm{SP} 500_{\mathrm{app}}-\left(1-\tau_{\mathrm{d}}\right) * \mathbf{r}_{\mathrm{t}}\right] .
$$

$R_{a, i t}$ is the after-tax return on fund $i$ in year $t$, and we assume that capital gains on the S\&P 500 (SP500 $0_{a p p}$ ) are taxed at our "effective accrual tax rate" on unrealized gains. This implicitly assumes that there are no current capital gain realizations associated with the market portfolio.

This measure of risk-adjusted after-tax fund performance is not completely satisfactory, since it takes a one-period approach to measuring the riskiness of a portfolio that will be held for many periods. In the taxable setting, unlike the no-tax environment, it is not possible to consider the riskiness of returns on a period-by-period basis, because the realization-based tax structure ties together after-tax returns in different periods.

\subsection{Return Persistence}

For rational investors to adjust their mutual fund investments in response to historical differences in returns, past returns must help predict future performance. We therefore explore the degree of return persistence in our data set. We begin by estimating the degree of persistence of pretax and after-tax returns using our entire data sample. We estimate first-order autoregressions of the form 


$$
\mathrm{R}_{\mathrm{it}}=\zeta_{\mathrm{t}}+\rho^{*} \mathrm{R}_{\mathrm{it}-1}+v_{\mathrm{it}}
$$

where $\mathbf{R}_{\mathrm{il}}$ denotes the return on fund $\mathrm{i}$ in year $\mathrm{t}$, and $\zeta_{\mathrm{t}}$ is a year-specific intercept term. We also estimate similar models for risk-adjusted returns, for after-tax returns, and for the tax burden on different funds.

Table 6 reports the resulting estimates. We find positive persistence across years for each of the measures of fund performance. For relative returns, the autocorrelation coefficient is 0.269 over the 1993-1998 period. The autocorrelation of the relative after-tax return is somewhat higher: 0.278 over this period. Perhaps more importantly for our analysis, there is substantial persistence in the estimated tax burden; the autocorrelation of $T_{i t}$ is estimated at 0.265 . This suggests that an investor who was concerned about minimizing the tax burden associated with a mutual fund investment could use past evidence on a fund's tax burden to predict the future burden of the fund. We interpret this as evidence of persistence in managerial styles. For example, fund managers who pursue low-turnover strategies are likely to generate relatively low tax burdens year after year.

The remaining panels of Table 6 show the autocorrelation of one-factor risk-adjusted return measures and the associated 'risk-adjusted tax burden.' These autocorrelations are greater than those of relative returns, i.e. returns that do not use a regression-based risk-adjustment strategy. With riskadjusted returns, we find autocorrelations of pretax and after-tax returns of more than 0.29 . The autocorrelation of the tax burden is estimated at 0.277 . These findings support the notion that an investor could predict future tax burdens by studying the past performance of a mutual fund.

Our persistence estimates are significantly higher that those of Carhart (1997) and Gruber (1996), although Ippolito (1992) reports return autocorrelations that are similar to ours. It is difficult to compare our measures of return persistence to the measures in many other studies, since much of the previous literature has used measures of persistence of fund return across deciles of the return distribution, rather than autocorrelation coefficients. We suspect that our higher-than-usual autocorrelations are a result of the data sample that we are analyzing. The years 1993-1998 experienced persistently high equity returns, and there was persistence in the nature of these returns, with large capitalization growth stocks leading the 
market higher. The persistence of returns across sectors should generate persistence in the nature of returns for different funds, for example with growth-oriented large capitalization funds doing well year after year. Another factor that explains our high persistence values may be our relatively modest risk correction. Controlling for market capitalization, value/growth, and momentum effects reduces our estimates of the persistence of mutual fund returns.

\section{The Determinants of Mutual Fund Tax Burdens}

The dispersion of tax burdens across mutual funds may contribute to differences in the net cash inflows to different funds, but it is also of interest in its own right. In this section, we explore the characteristics of mutual funds that are associated with high tax burdens. This analysis necessarily involves relating tax burdens to a set of variables, many of which are endogenous, and under the control of the fund manager. The rate at which the manager turns over the fund portfolio is a clear example. We do not attempt to develop a theory of why managers realize gains; Barclay, Pearson, and Weisbach (1998) have begun to explore this issue. We summarize the correlates of high tax burdens, and leave model building to future work.

We estimate partial correlation coefficients by fitting regression models of the form

$$
\mathrm{T}_{\mathrm{it}}=\alpha+\mathrm{X}_{\mathrm{it}} * \beta+\mathrm{v}_{\mathrm{t}}+\zeta_{\mathrm{it}}
$$

where $T_{i t}$ denotes our estimate of the tax burden on fund $i$ in year $t$ and $X_{i t}$ is a set of fund characteristics. The set of explanatory regressors, $\mathrm{X}_{\mathrm{it}}$, includes: the turnover of stocks in the fund; an indicator variable for whether or not the fund is an index fund, which would indicate a reduced need for trading; an indicator for whether or not the fund is a tax-managed fund; and an indicator variable for new management taking charge of the fund in recent years, which may indicate a shift in portfolio strategy. We also include several years of lagged fund inflows as a share of fund assets, since a fund experiencing inflows does not need to sell shares to raise cash, and consequently has a greater opportunity to pursue a low realizations strategy. We also include the fund's current pretax returns, the fund's lagged tax burden, 
and a set of indicator variables for fund styles (large-cap growth, small-cap value, etc.), since realization differences across investment styles may influence investor tax burdens.

Table 7 reports two sets of regression results. In the first, all funds are assigned equal weight, while in the second, we weight each fund-year's observation the fund's total assets at the end of the previous year. We focus on the findings from the weighted regressions, since they describe the behavior of the average dollar invested in mutual funds. The results suggest several patterns. First, current and lagged turnover are both important correlates of a fund's tax burden. A twenty percentage point increase in annual turnover, from the mean of 79 percent to 99 percent, is associated with an 14 basis point increase in the fund's tax burden. While current turnover is associated with a higher tax burden, higher past turnover has a negative effect on the current tax burden. This is conditional on current turnover, and it presumably reflects the fact that assets that have been purchased recently are likely to have smaller embedded capital gains than assets that were purchased in the more distant past. As expected, the current tax burden is positively related to the share of a fund's value at the previous year-end that is comprised of unrealized appreciation on fund assets.

Our finding that current turnover is an important predictor of a fund's tax burden stands in contrast to some recent industry analyses, such as Belden (1998) and Barbee (1999), which suggest the opposite. This may be because we focus on the marginal impact of turnover in explaining tax burdens, rather than the total explanatory power of turnover in accounting for tax burden differences. In principle, turnover need not lead to higher tax burdens. A fund manager who realizes losses and holds gains may have a higher turnover rate than one who does not harvest losses, but the resulting tax burden on such a fund may be lower than that on a comparable, but lower-turnover, fund. Our empirical findings suggest that turnover is not typically directed at tax-minimization.

A number of other findings in Table 7 warrant comment. There is substantial positive serial correlation in the tax burdens on different funds. A ten basis point increase in the tax burden on a fund in the current year predicts between a one and two basis point increase in the tax burden next year. Index funds have substantially lower tax burdens than other funds. The average differential between the tax 
burden on index funds and other funds is roughly 45 basis points. The coefficient on the tax-managed fund indicator suggests that these funds also have tax burdens about 40 basis points below other funds. Managerial changes and past inflows are also correlated with current tax burdens. Funds with new managers have tax burdens about 40 basis points higher than other funds. Funds with higher inflows in previous years display lower tax burdens than funds with lower past inflows. Since inflows are persistent, funds with higher past inflows probably face a reduced need to sell securities to meet redemptions.

The information in Table 7 provides some background on the source of fund-to-fund differences in tax burdens. Many of the factors that we have used to "explain" fund tax burdens can be affected by fund managers. Chevalier and Ellison (1997) note that the compensation of such managers is highly dependent upon their assets under management. In this setting, the impact of tax burdens on a fund's asset base, which will be mediated through their effect on net inflows, becomes a central issue. This is the empirical question to which we now turn.

\section{Measuring Mutual Fund Inflows}

To measure the net inflows to equity mutual funds, we rely primarily on data reported by Morningstar. We compute net inflows from annual data on fund assets. Morningstar reports total assets, as well as the net asset value (NAV) for each fund share, at the end of each calendar year. We estimate annual net inflows as a fraction of assets at the end of the previous year, $\mathrm{I}_{\mathrm{t}}^{\mathrm{u}}$, as follows:

$$
\mathrm{I}_{\mathrm{t}}^{\mathrm{u}}=\text { Assets }_{1} / \text { Assets }_{\mathrm{t}-1}-\left(\mathrm{NAV}_{1}+\mathrm{DIV}_{\mathrm{t}}+\mathrm{GAINS}_{1}\right) / \mathrm{NAV}_{1-1}
$$

This measure subtracts from the growth in fund size the portion attributable to returns on assets in the fund at the end of the previous year. It is the most commonly used measure of inflows in the empirical literature. We adjust this measure, following Ippolito (1992), to account for the fact that new shares are purchased throughout the year. We therefore compute a modified inflow measure $\left(\mathrm{I}_{t}\right)$ as:

$$
\mathrm{I}_{\mathrm{t}}=\mathrm{I}_{\mathrm{r}}^{\mathrm{u}} /\left(1+\mathrm{R}_{\mathrm{t}} / 2\right)
$$

where $\mathrm{R}_{1}$ denotes the fund's return over the calendar year. In (7), DIV and GAINS $\mathrm{t}_{\mathrm{t}}$ correspond to dividend and capital gain distributions, respectively. 
Our measure of net inflows distinguishes inflows that result from reinvestment of dividends and realized capital gains from net 'new money' inflows. (Net inflows including such reinvestments could be

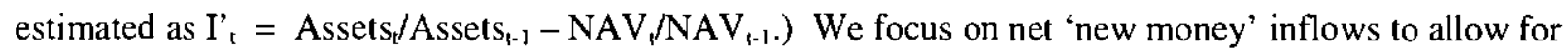
the possibility that such inflows are more sensitive to relative performance than reinvested dividends and capital gains. Since roughly 90 percent of dividends and realized gains are reinvested at equity mutual funds, this seems like a plausible assumption. To explore the sensitivity of our findings to our assumption that 'new money' inflows are critical, we have estimated our basic regression equations using both I', and $I^{u}{ }_{l}$, rather than $I_{t}$, the dependent variable. The results are similar to the findings that we report using $I_{t}$.

One potential difficulty with estimating mutual fund net inflows from year-end information on fund assets deserves note. The cash inflow arising from the purchase of a share depends on the NAV at the time of the purchase. Measures of inflows such as (7) and (8), which are based on year-to-year changes in fund NAV and size, miss this within-year purchase timing effect. Especially when the return on a fund is a large positive or negative number, it is possible for the annual difference in assets under management to diverge from the actual inflows during the year. To evaluate the empirical importance of this bias, we obtained monthly data on fund net inflows for a small sample of equity mutual funds in the last few years of our sample period. The Financial Research Corporation provided these data. We then compared our estimate of the fund net inflow based on annual data with the actual sum of the monthly fund net inflows, and we found that the two estimates of net inflows diverged relatively little for most funds. Further detail on this calculation is presented in an earlier version of this paper.

The average fund in our sample experienced net inflows of 21.1 percent of beginning-of-year assets. Average inflows as a share of initial assets are smaller, 8.9 percent per year, when we weight funds by the initial asset value. This disparity suggests that on average larger funds experience smaller inflows, relative to assets, than smaller funds. Median net inflows are also smaller than mean net inflows. The median asset-weighted fund inflow is 3.5 percent. The difference between the mean and the median is indicative of substantial skewness in net inflow rates across funds. This is supported by summary statistics: the interquartile range for inflows as a share of initial assets was' 38.8 percent (unweighted) and 
20.5 percent (asset weighted). Forty-three percent of all fund-years in our sample showed net outflows rather than inflows. The wide differences in the inflow experience of different funds are the result of many factors. We now investigate whether differences in the tax burdens that funds place on their investors are one of them.

\section{The Determinants of Mutual Fund Net Inflows}

The starting point for our analysis of mutual fund inflows is a regression model relating inflows to past returns and other fund characteristics:

$$
I_{i, t}=R_{i, t-1} * \theta+X_{i, t} * \phi+v_{t}+v_{i, t} .
$$

In this equation, $I_{i, t}$ is the fund's inflow, $R_{i, t-1}$ denotes a fund's past returns, possibly on a risk-adjusted basis and possibly for a period of several years, and the $\mathrm{X}_{\mathrm{i}, \mathrm{r}}$ vector includes other factors that may explain fund inflows. We estimate models in which $\mathrm{R}_{\mathrm{i}, \mathrm{r}-\mathrm{l}}$ denotes lagged pretax returns, lagged after-tax returns, or both sets of returns, so that we can evaluate the relative predictive power of the two sets of return measures. Some of the variables included in $\mathrm{X}_{\mathrm{i}, \mathrm{l}}$ are 'control variables' that may influence inflows for reasons unrelated to returns. These include fund age, the initial size of the fund, fund turnover, the fund's objective, and the fund's stock of unrealized capital gains.

The functional form linking past returns to current inflows has been an active subject of previous research. Sirri and Tufano (1998) and Chevalier and Ellison (1997) find substantial nonlinearities in this relationship: funds in the highest return strata experience large inflows relative to those with slightly lower returns. This suggests a 'stars effect' in fund inflows. We therefore present both ordinary least squares results from equation (9), in which lagged returns have a linear effect on fund inflows, as well as results from a specification that allows for different effects of returns on funds whose annual returns are in different quantiles of the return distribution. We also allow for a different derivative effect in the top five percentiles of each performance measure. Our findings about the relative importance of pre-tax and after-tax returns are relatively robust with respect to these changes of specification. 


\subsection{Fund Inflows and Returns: Results Without Other Covariates}

Table 8 presents the estimates from simple linear regressions that exclude any factors other than lagged returns from the equations explaining inflows. Table 9 presents analogous results based on spline regressions that allow for nonlinearity in the performance-inflow relationship. Each table presents results in which the explanatory variable, the fund return, is measured relative to the S\&P 500 Index return. The tables also show results using fund returns that have been risk-adjusted using the one-factor risk adjustment procedure that we described above.

Each table includes results of regression models that are estimated weighting all funds equally, and that are estimated with observations on each fund weighted by fund assets. We report three regressions for each specification. The first simply relates fund inflows to lagged pretax returns, and the second relates inflows to both lagged pretax returns and the lagged tax burden. This provides a direct test of whether the tax burden has any explanatory power for fund inflows.

The results in Table 8 demonstrate the substantial explanatory power of lagged pretax returns in describing net mutual fund inflows. The return measure that we construct as the difference between a fund's return and the return on the S\&P 500 has substantially more explanatory power than our one-factor risk-adjusted return. A one hundred basis point increase in a fund's return predicts between a two and a three percentage point increase in the fund's net inflows in the following year.

The findings in Table 8 are consistent with the view that some mutual fund investors are attuned to the tax burdens that their funds impose. When we include the tax burden in a regression model for net inflows, we clearly reject the null hypothesis that the tax burden does not affect such inflows. The findings suggest substantively important effects. A one hundred basis point increase in the tax burden on a fund is associated with between a four and an eight percentage point decrease in subsequent inflows. Thus a fund that moved from the $75^{\text {th }}$ percentile to the $25^{\text {th }}$ percentile in measured tax burden, which would correspond to a 0.8 percentage point change in tax burden, would experience an increased net inflow rate of between 3 and 7 percentage points. 
One potential explanation of our findings is that index funds have grown rapidly during our sample period, and that they are relatively tax-efficient funds. To test this hypothesis, we excluded the Vanguard Index 500 fund from our regression sample. Since this fund accounts for a very large fraction of the total assets under indexed management, excluding it from the equations that are weighted by fund value removes most of the contribution of index funds to the estimates. The coefficient on the tax burden variable changes from $-8.69(0.85)$ to $-8.86(0.90)$ when we exclude the Vanguard Index 500 , so this does not seem to be a key factor in our results.

Table 9 reports results similar to those in Table 8, except that the specification now allows for a nonlinear performance-inflow relationship. We use a spline function with five knots, at the $20^{\text {th }}, 40^{\text {th }}$, $60^{\text {th }}, 80^{\text {th }}$, and $95^{\text {th }}$ percentiles of the pretax return distribution, to capture nonlinear effects. This specification allows different effects of returns on inflows at different parts of the return distribution. Our knot points are set based on the distribution of fund returns for the entire sample period. While this could lead to a high concentration of returns from one year in one quintile, this does not appear to happen.

Table 9 shows the effect of using the spline specification rather than the linear specification. Each of the coefficients indicates the marginal effect of returns for funds whose returns fall in particular parts of the return distribution. We present results using both pre-tax and after-tax returns, but we do not attempt to separately distinguish the effects of taxes and returns in these specifications.

The findings suggest substantial variation in the link between lagged returns and fund inflows at different points in this distribution. Like Sirri and Tufano's (1998) findings, the marginal effect of performance on net inflows is greater above the median of the return distribution than below the median. Consider the predicted difference in inflows between a fund that realizes and distributes capital gains of two percent of asset value, and a fund that distributes gains of five percent of asset value. Assume that the total return on the two funds is the same, so that the only effect of the difference in realizations is a difference in tax burden. Given our assumption about the tax rate on capital gains, the fund realizing gains of five percent would generate after-tax returns 60 basis points lower than those of the first fund. This return differential would result in a predicted inflow 3.3 percentage points smaller (using the relative 
retum specification) or 2.5 percentage points smaller (using the risk-adjusted retum specification) for the fund with the high tax burden.

The results in Tables 8 and 9 are based on data for the entire 1993-1998 sample period. There have been important changes during our sample period in the extent to which the tax consequences of mutual fund investing are discussed in the investment press. When Jeffrey and Amott (1993) published their paper on investment returns for taxable clients, tax issues received much less attention than they do today. Morningstar now reports after-tax performance statistics for mutual funds, and popular magazines such as Business Week print data on after-tax retums. These developments suggest that investors may have become more sensitive to after-tax returns over time. To test this possibility, we estimated regression models like those in Table 8 with separate coefficients on the tax burden variable for each year. The negative effect of the tax burden on retums was greater in the last three years of the sample (1996, 1997, and 1998) than in the first two, although the year with the single largest effect of the tax burden is 1995. The time series of coefficient values nevertheless provides some support for the growing importance of tax-aware investing.

\subsection{Fund Characteristics, Retums. and Inflows}

The foregoing regression models compare the predictive power of pretax and after-tax retums in forecasting mutual fund inflows, but they do not allow for any of the wide range of other attributes of individual mutual funds that might affect inflows. Other studies have allowed for a variety of such factors. Chevalier and Ellison (1997), for example, consider the age of a mutual fund and its size as potential determinants of fund inflows. Barclay, Pearson, and Weisbach (1998) model fund growth rates as a function of lagged fund retums, a set of indicator variables for fund type, a measure of the fund expense ratio, front end load, and the funds' unrealized capital gains overhang. Their study is in many ways the closest antecedent to our work, and we try to include many of their control variables in our regression specifications. Their results are based on a data sample from the 1976-1992 period, while our results are for a separate and more recent period. There have also been changes over time in marginal tax rates and in the relative importance of taxable and tax-exempt (retirement account) investors in the mutual 
fund market. Despite these changes, our findings about the relationship between fund inflows and lagged returns are broadly consistent with the findings in Barclay, Pearson, and Weisbach (1998).

We add control variables to our regression models for fund inflows for two reasons. First, it is possible that pretax and after-tax returns are correlated with these other fund attributes in ways that lead to spurious conclusions about how returns affect inflows. Second, some variables other than lagged pretax and post-tax return, particularly the fund's capital gains overhang, are of independent interest for analyzing how taxation affects the behavior of mutual fund investors.

We expand our basic regression specification by including the following covariates: age of the fund, which we specify as two indicator variables, one for funds that are between three and eight years old, and another for funds that are older; fund size, which is measured in logarithms and has proven to be an important predictor of inflows in previous studies; the fund's expense ratio in the previous year; an indicator variable for whether the fund has a load; and the lagged fund inflow, to allow for persistence in fund flows. We also include a set of indicator variables for eight types of equity mutual funds, to capture differences across funds that are related to investment style. We also include the median market capitalization and average price/book ratio of the stocks in each fund's portfolio as an additional measure of the fund's investment strategy. Finally, we include the Morningstar 'rating' assigned to a fund; these ratings are widely quoted and may significantly affect net inflows.

To avoid presenting an unwieldy number of regressions, we limit our focus in two ways. First, we concentrate on models in which lagged returns and tax burdens have a linear effect on inflows. Since the spline specifications in Table 9 generated results that were broadly similar to those from the linear specification, this restriction does not seem likely to affect our central conclusions. Second, we limit our analysis to the simplest measure of risk-adjusted returns, the one that subtracts the return on the S\&P 500 from the return on each equity mutual fund. Since this return measure had the highest explanatory power in the earlier specifications, and since our findings about the importance of the tax burden variable were relatively insensitive to our choice of the risk-adjustment algorithm, this restriction again should not affect our conclusions. 
Tables 10 and 11 report the central findings from our expanded specification. Some of the new covariates have substantial effects on fund inflows, and adding the controls improves the explanatory power of the regression model, but the central results on the difference between pre- and post-tax returns are not affected by adding the controls. The results continue to suggest that funds with higher tax burdens experience lower inflows than similar funds with lower tax burdens.

A number of the control variables have effects that are of interest in their own right. The findings suggest that inflows are greater at younger funds, and that the proportional inflow of assets is smaller at large funds. The coefficients on the objective variables indicate that, controlling for fund performance, inflows to 'small company' funds have been greater than inflows to other types of domestic equity funds. The coefficients on the expense ratio variable are negative but statistically insignificant, and the coefficient on the turnover variable provides weak evidence that investors prefer funds with less turnover. The Morningstar 'rating' is on a 5-point scale; increasing the rating by a point raises by about 10 percentage points the expected value of net inflows.

If taxable investors are concerned about purchasing shares in a fund that might realize gains and thereby burden them with higher taxes, a larger unrealized capital gain could be associated with smaller fund inflows. Barclay, Pearson, and Weisbach (1998) presented results confirming this prediction. Columns 3 and 4 of Tables 10 and 11 report results of inflow equations that include the capital gains overhang variable. The results support the view that capital gains overhang is a statistically significant determinant of fund inflows. The weighted results imply that a ten percent increase in the share of unrealized capital gains relative to fund assets is associated with a reduction of between 2 and 5 percentage points in fund inflows.

\subsection{Alternative Approaches to Capital Gains}

The foregoing results are based on a measure of tax burden that aggregates long-term and shortterm capital gains, and that assumes that any short-term gains are taxed at the long-term capital gains tax rate. While we cannot disaggregate the components of capital gain realizations for funds that have 
disappeared, we can use the sample of funds in the January 1999 Morningstar data release to assess possible biases from aggregating capital gains.

Table 12 presents coefficient estimates from models like those in Table 11 . The estimates in the first column use a tax-burden measure that aggregates capital gains components, just like the estimates in Table 11, while the results in the second column use a tax burden measure that disaggregates these components and applies the income tax rate to the short-term component of capital gains. The sample period for the results in Table 12 is smaller than that for the results in Table 11, and the standard errors for the coefficients are correspondingly larger.

The results in Table 12 suggest that the coefficient estimates for the tax burdens in Tables 10 and 11 may be biased away from zero. Disaggregating capital gain realizations into short-term and long-term components and applying the higher income tax rate to the short-term component changes the estimated tax burden coefficient from -4.46 to -3.69 . The large standard error associated with this coefficient estimate, 0.79 , makes it difficult to draw any definitive conclusion from this result. The findings in Table 12 are encouraging, since they suggest that the basic pattern of results that we find using an aggregated measure of capital gain realizations still emerges when we use the disaggregate data on capital gains.

A separate measurement issue that warrants some investigation is our treatment of the accrual equivalent tax rate on accruing but unrealized capital gains. For most of the funds in our sample, undistributed capital gains account for at least half of the pretax return. Until now, we have assumed that the accrual equivalent tax burden on these gains is 10 percent, half the statutory long-term capital gains tax rate in 1998. Most previous research on the taxation of fund returns assumes that undistributed capital gains are effectively untaxed.

To explore the sensitivity of our findings to our assumption about the tax burden on unrealized gains, we estimated regression models like those in Table 11, but with different assumptions about the tax burden on unrealized gains. Table 13 reports our findings. The tax burden measure in the first column assumes that the effective tax rate on accruing capital gains is 10 percent, while the second column assumes that accruing unrealized gains are untaxed. Varying the effective tax rate on undistributed gains 
has a large effect on the estimated coefficient, but there is almost no effect on this coefficient's statistical significance. Reducing the effective tax rate from 10 percent to zero changes the t-statistic of the tax burden coefficient from 4.79 to 4.75 . These results suggest that the broad picture that emerges from our empirical analysis is unaffected by our assumption about the effective tax rate on a fund's accruing gains. 4.5 The Effect of Tax Burdens on Inflows to "Institutional" Funds

Our empirical findings for a large sample of retail funds are consistent with the hypothesis that taxable investors are allocating their money across funds in part in response to difference in the fund's after-tax returns. It is nevertheless possible that these results are not driven by the behavior of taxconscious individual investors seeking to avoid tax liabilities, but by other factors. The tax burden on funds that generate returns in the form of capital gains, particularly unrealized capital gains, is lower than the tax burden on funds that generate more of their income from dividends. If investors "chase" capital gains, then inflows could exhibit the pattern that we find even if investors are not concerned about the after-tax performance of their funds. More generally, given the limited attention that the tax status of various funds received until the middle of our sample period, there is some question of whether tax-aware mutual fund investing is the best explanation for our findings.

One way to evaluate this question is to study the relationship between lagged returns, and lagged tax burdens, and fund inflows for a set of funds that is unlikely to be held by taxable investors. We do this by studying inflows to institutional mutual funds. Most institutional investors, such as pension funds and endowments, are not taxable, so they should be concerned with pretax rather than after-tax returns. Morningstar identifies some funds as "institutional," but there is substantial heterogeneity within this group. Funds may be included in this category because they have large minimum balance requirements, or because they restrict the set of investors who may purchase funds.

We identified a sample of 751 fund-years corresponding to 'institutional' funds over the 19931998 period, and we estimated our basic regression models with these data. Table 14 presents our findings, which provide only mixed support for our "taxable investor" interpretation. For the set of institutional funds, there is a strong positive effect of pretax returns on net inflows, and a negative effect 
of the fund's tax burden. The coefficient on the pretax return in the linear specification is $2.74(0.49)$, compared with $1.90(0.16)$ in our sample of retail funds. The coefficient on the tax burden for the institutional funds is $-5.97(1.66)$, compared with $-3.79(0.79)$ for the noninstitutional funds. This negative coefficient on the tax burden variable, for a set of funds that is unlikely to be held by taxable investors, is a substantial challenge to the "tax aware" interpretation of the earlier results. We do not have a convincing explanation at this stage of what accounts for this finding; we are continuing to explore various possibilities. It may be that even institutional funds are held in substantial part by taxable investors, and that their behavior accounts for enough of the variation in inflows to institutional funds to generate results like those for non-institutional funds. Some investment-management firms, for example, may offer private clients the opportunity to invest through institutional funds. These clients may be among the most tax-conscious in the mutual fund marketplace.

A different finding from the institutional fund sample is supportive of the view that investors in retail funds consider taxes in their investment decisions. For the institutional fund sample in Table 14, there is no evidence that capital gains overhangs discourage inflows. The coefficient on the capital gains overhang variable is four times larger for the retail funds than for the institutional funds.

\section{Gross Inflows and Gross Outflows}

The data from Morningstar and most other sources make it possible to construct net inflows, but not gross purchases and gross sales, at individual mutual funds. As a result, most previous research, with prominent exception of Chordia's (1996) study of the relationships among redemptions, load charges, and fund cash balances, has analyzed the determinants of net inflows. The Investment Company Institute (1999) presents aggregate evidence showing that net inflows are the result of large, and in part offsetting, gross inflows and gross redemptions. In recent years gross redemptions for equity, bond, and hybrid funds have been just under 20 percent of total assets.

There may be important differences in the way an individual fund's return history and other characteristics affect gross inflows and gross redemptions. To explore these issues, we collected gross 
inflow and gross outflow data for a small subset of funds. We identified the 200 largest mutual funds in our sample in each of the past five years, and searched the SEC's EDGAR archive (at www.sec.gov), the private edgar-online page (www.edgar-online.com), and fund web pages themselves for reports detailing these funds' share purchases and redemptions. The resulting dataset contains 686 fund-years of data over the period 1994-1998. Limiting our sample in this way avoids explicit conditioning on mutual funds' subsequent growth, except to the extent that this growth affects our ability to gather fund data.

Table 15 reports summary measures based on these data. For all 686 fund-years, the gross inflow averages 36.6 percent of beginning-of-year assets, while the average gross outflow amounts to 30.5 percent of assets. The flows are somewhat smaller, an inflow of 36.1 percent and an outflow of 26.5 percent, when we weight funds by their total assets under management. The outflows are not the result of investors taking distributions of dividends or realized gains. The average reinvestment rate for firms in our 1998 sample was over 93 percent, and the minimum was 81 percent. Thus these statistics suggest that the net inflow measures that we have analyzed prior to this point mask much larger gross inflows and gross outflows.

If taxable investors observe persistence in tax-management skills and allocate new investment according to after-tax performance, then we should find a strong effect of lagged returns on gross inflows. Alternatively, if investors are reluctant to sell shares of funds that have accrued substantial undistributed capital gains, which are typically "tax efficient" funds, then we might find a positive relationship between measured tax burdens and subsequent gross outflows. Both explanations could yield a negative link between net inflows and tax burdens, but they cannot be distinguished without data on gross flows.

Table 16 reports regression results in which the dependent variables are the net inflow (column 1), the gross inflow (column 2) and the gross outflow (column 3) for each fund in our restricted sample. The equations in the first part of each panel do not include the capital gains overhang variable, while those in the second part of each panel do. In addition, we have divided the results into Panel A and Panel $\mathrm{B}$, corresponding to unweighted and weighted results. The independent variables in all equations are the lagged relative return, the lagged relative tax burden, and a full set of year dummies. In Panel A, the first 
column shows that the effect of pretax returns and tax burdens is similar in this restricted sample and in the much larger Morningstar sample that we used above. The pretax return has a positive effect on net inflows, and the tax burden has a negative effect. The second and third columns present results that disaggregate these effects. Most of the effect of pretax returns on net inflows is due to a strong effect of pretax returns on gross inflows. The effect of pretax returns on gross outflows is minimal.

High tax burdens are associated both with lower gross inflows and lower gross outflows. The effect of tax burdens on net inflows is negative and significant, as we would expect if taxable investors were allocating their new money to mutual funds in part based on past after-tax returns. Past tax burdens have a negative effect on outflows, although this effect is never statistically significant.

The results in Table 16 with respect to the interaction between gross flows and the undistributed capital gains overhang also confirm our earlier results using the Morningstar sample. A high capital gains overhang significantly reduces net inflows to a fund. This is the result of a large negative effect on gross inflows, and an offsetting (but weaker) negative effect on gross outflows. The gross inflow effect is consistent with taxable investors trying to avoid funds that will accelerate the distribution of capital gains. It provides additional support for Khorana and Servaes' (1999) finding that new funds are more likely to be created in parts of the mutual fund marketplace that are occupied by established funds with substantial capital gains overhangs. The gross outflow effect is consistent with taxable investors being reluctant to sell shares in, and realize gains in, funds that have large embedded capital gains. These results are generally supportive of the view that fund flows respond to factors that taxable investors would consider in determining their fund allocations. The value of the gross flows data is clearly illustrated by the interesting findings with respect to gross redemptions, which could not be detected using only information on net fund flows.

\section{Conclusion}

This paper suggests that the individual income tax burden that fund investors face when they hold a fund is negatively correlated with fund inflows. This is consistent with the view that taxable investors 
consider the impact of income taxation on asset returns when they decide which mutual fund shares to purchase or redeem. Mutual funds that offer higher after-tax rates of return attract greater inflows than those with lower after-tax returns, even after we control for a fund's pretax return. We also find that a fund's unrealized capital gain "overhang" negatively affects net fund inflows, even though it also reduces the likelihood of redemptions. This result is consistent with Barclay, Pearson, and Weisbach's (1998) findings for an earlier data sample. While the inflow effects associated with changes in income tax burdens or capital gains overhang are modest, they are comparable in magnitude to the effects of fund expense ratios on inflows.

Our findings suggest that taxation may play a role in the way investors choose their mutual funds. Yet there are several reasons for caution in interpreting the results. One is that for part of our sample period, particularly the early years, investors would have to work hard to obtain information on a fund's after-tax returns. The barriers to information acquisition have fallen in recent years, and the apparent impact of tax burden on fund inflows has increased. The concern that investors might not be aware of fund tax circumstances also applies to our findings, and perhaps even more to findings based on earlier sample periods, with respect to the impact of unrealized gains on fund inflows.

A second concern is that a substantial share of the assets at mutual funds, roughly 35 percent at year-end 1998, and a much higher share in some large equity funds, is held in tax-deferred retirement accounts. Investors holding funds in these accounts should not be sensitive to the tax burden measures that we study. Ideally, we would like to measure the fund inflows that are attributable to taxable individual investors, and to study how those flows respond to various factors. We are not aware of any data source that provides the requisite information on fund flows, however. The simple existence of a substantial body of non-taxable money in equity mutual funds is not inconsistent with our findings. It does, however, imply that taxable investors are even more sensitive to tax burdens than our results otherwise suggest.

A third concern emerges from our findings with respect to institutional rather than retail mutual funds. Since institutional funds are less likely to attract taxable investors than their retail counterparts, 
one would expect a smaller impact of tax variables on inflows to such funds. Our results confirm this with respect to the impact of the capital gains overhang variable, but not with respect to the impact of the tax burden on fund returns.

There are other puzzles associated with mutual fund flows and the importance of taxable investors. One is the relatively slow growth of "tax efficient" mutual funds in the mid-1990s. A number of major mutual fund complexes, including Vanguard and Charles Schwab, have introduced funds that are targeted to taxable investors who are concerned about capital gain realizations. These funds also try to reduce their dividend income relative to capital gains. While these funds have grown more rapidly than other mutual funds since they were introduced, they still represent a small share of the mutual fund marketplace. In 1998 (1996), tax-managed funds accounted for 0.4 percent (0.14 percent) of the assets of the equity mutual funds in our sample. If flows to existing mutual funds are sensitive to the tax burden on these funds returns, one would have expected greater growth of tax-efficient mutual funds. One response to this concern is that index funds have grown rapidly during the last decade, and most index funds represent relatively tax-efficient investment vehicles.

Finally, the general growth of mutual funds as vehicles for taxable investors to hold common stocks raises fundamental questions about the degree to which taxes affect investor behavior. Because mutual funds cede decisions about realizing gains and losses from the individual investor to a mutual fund manager, they reduce the individual's control over portfolio decisions with substantial tax consequences. Mutual fund investing may offer other advantages that offset the potential increase in investor tax burdens, such as the opportunity to diversify portfolio holdings. Studying the determinants of investor choices between common stocks and mutual funds is a natural issue for further investigation. 


\section{REFERENCES}

Barbee, Olivia (1999). "Seven Habits of Highly Tax-Efficient Investors," Morningstar Fund Investor (September).

Barclay, Michael, N. Pearson, and Michael Weisbach (1998), "Open End Mutual Funds and Capital Gains Taxes," Journal of Financial Economics 49, 3-43.

Bhabra, Harjeet, Upinder Dhillon, and Gabriel Ramirez (1999), "A November Effect? Revisiting the Tax Loss Selling Hypothesis," mimeo, Concordia University.

Chevalier, Judy and Glenn Ellison (1997),"Risk Taking by Mutual Funds as a Response to Incentives," Joumal of Political Economy 105, 1167-1200.

Carpenter, Jennifer and Anthony Lynch (1999). "Survivorship Bias and Attrition Effects in Measures of Performance Persistence," Journal of Financial Economics 54, 337-374.

Chordia, Tarun (1996), "The Structure of Mutual Fund Charges," Journal of Financial Economics 41, 3-39.

Constantinides, George (1984), "Optimal Stock Trading with Personal Taxes: Implications for Prices and the Abnormal January Returns," Joumal of Financial Economics 13, 65-89.

Dammon, Robert and Chester Spatt, (1996), "The Optimal Trading and Pricing of Securities with Asymmetric Capital Gains Taxes and Transactions Costs," Review of Financial Studies 9, 921-952.

Dickson, Joel, and John Shoven (1995). "Taxation and Mutual Funds: An Investor Perspective," in J. Poterba, ed., Tax Policy and the Economy, Volume 9 (Cambridge: MIT Press), 151-181.

Gruber, Martin (1997), "Another Puzzle: The Growth in Actively Managed Mutual Funds," Journal of Finance 51, 783-810.

Hendricks, Darryll, Jayendu Patel, and Richard Zeckhauser (1994), "Investment Flows and Performance: Evidence from Mutual Funds, Cross-Border Investments, and New Issues," in Ryuzo Sato, Richard Levich, and Rama Ramachandran, eds., Japan, Europe, and International Financial Markets: Analytical and Empirical Perspectives (Cambridge: Cambridge University Press).

Investment Company Institute (1999). The Mutual Fund Fact Book. (Washington: Investment Company Institute).

Ippolito, Richard (1992), "Consumer Reaction to Measures of Poor Quality: Evidence from the Mutual Fund Industry," Joumal of Law and Economics 35, 45-70.

Jeffrey, Robert H. and Robert D. Arnott (1993), "Is Your Alpha Big Enough to Cover Its Taxes?" Journal of Portfolio Management (Spring), 15-25.

Kennickell, Arthur, Martha Starr-McCluer, and Brian Surette (2000). "Changes in U.S. Family Finances at the End of the 1990s: Results from the 1998 Survey of Consumer Finances." Federal Reserve Bulletin 86 (January).

Khorana, Ajay, and Henri Servaes (1999). "The Determinants of Mutual Fund Starts," Review of Financial Studies $12(5), 1043-1073$. 
Poterba, James (1987),"How Burdensome Are Capital Gains Taxes?," Journal of Public Economics 33, 153 172.

Poterba, James (1998). "The Rate of Return to Corporate Capital and Factor Shares: New Estimates Using Revised National Income Accounts and Capital Stock Data," Carnegie-Rochester Conference Series on Public Policy 48 (June), 211-246.

Poterba, James (1999), "Unrealized Capital Gains and the Measurement of After-Tax Portfolio Performance," Journal of Private Portfolio Management 1 (Spring), 23-34.

Poterba, James, and Andrew Samwick (2000). "Taxation and Household Portfolio Composition: Evidence from Tax Reforms in the 1980s." NBER Working Paper 7392.

Sirri, Erik, and Peter Tufano (1998), "Costly Search and Mutual Fund Flows," Journal of Finance 53, 15891622.

Stiglitz, Joseph (1983), "Some Aspects of the Taxation of Capital Gains," Journal of Public Economics 21, 257-294.

U.S. Congressional Budget Office (1999), The Contribution of Mutual Funds to Taxable Capital Gains (Washington: U.S. Congressional Budget Office).

Warther, Vincent (1995), "Aggregate Mutual Fund Flows and Security Returns," Journal of Financial Economics 39, 209-236. 
Table 1: Ownership of Taxable Mutual Funds, 1995

\begin{tabular}{|l|l|l|}
\hline Household Income Category & $\begin{array}{l}\text { Total Number of Households } \\
\text { Owning Taxable Mutual Funds }\end{array}$ & $\begin{array}{l}\text { Total Holdings of Taxable } \\
\text { Mutual Funds }\end{array}$ \\
\hline$<\$ 50,000$ & 5.73 million (47.2 percent) & 293 billion (25.6 percent) \\
\hline$\$ 50-100,000$ & $4.12(33.9)$ & $328(28.7)$ \\
\hline$\$ 100-150,000$ & $1.12(9.2)$ & $145(12.8)$ \\
\hline$\$ 150-250,000$ & $0.83(6.8)$ & $167(14.6)$ \\
\hline$>\$ 250,000$ & $0.35(2.9)$ & $211(18.4)$ \\
\hline Total & $12.15(100.0)$ & $1144(100.0)$ \\
\hline
\end{tabular}

Source: Authors' tabulations from 1995 Survey of Consumer Finances. Entries in parentheses are percentages of column totals. Returns are measured net of expenses.

Table 2: Summary Statistics on Mutual Fund Returns, 1993-1998 (5866 fund years)

\begin{tabular}{|l|c|l|l|}
\hline Retum Component & Mean & Median & Interquartile Range \\
\hline Pretax Return & 17.1 & 18.5 & 18.0 \\
\hline Dividend Yield & 1.0 & 0.6 & 1.6 \\
\hline Capital Gain Distributions & 8.3 & 7.1 & 8.9 \\
\hline Undistributed Capital Gain & 7.8 & 7.9 & 18.3 \\
\hline Tax Burden & 3.0 & 3.2 & 2.4 \\
\hline After-Tax Return & 14.1 & 15.1 & 16.1 \\
\hline $\begin{array}{l}\text { Taxes/Pretax Return (Conditional } \\
\text { on Pretax Return > 0) }\end{array}$ & 18.4 & 16.0 & 7.9 \\
\hline
\end{tabular}

Source: Authors' calculations using Morningstar Principia databases.

Table 3: Mean Pre-tax and After-Tax Returns, by Years, 1993-1998

\begin{tabular}{|l|l|l|l|l|l|}
\hline \multirow{2}{*}{ Year } & Sample & \multicolumn{3}{|l|}{ Fund-Weighted } & Asset-Weighted \\
\cline { 3 - 6 } & Size & Pretax Return & Tax Burden & Pretax Retum & Tax Burden \\
\hline 1993 & 509 & 12.7 & 2.7 & 13.8 & 2.8 \\
\hline 1994 & 644 & -1.8 & 0.9 & -0.7 & 1.1 \\
\hline 1995 & 773 & 30.5 & 4.7 & 32.6 & 4.9 \\
\hline 1996 & 1003 & 18.1 & 3.7 & 18.1 & 3.5 \\
\hline 1997 & 1330 & 23.4 & 3.7 & 25.7 & 3.8 \\
\hline 1998 & 1607 & 13.9 & 2.2 & 20.9 & 3.0 \\
\hline All Years & 5866 & 17.1 & 3.0 & 20.9 & 3.4 \\
\hline
\end{tabular}

Notes: Authors' tabulations using data from Morningstar 1994-1999 databases. Tax burden calculations assume a marginal tax rate of 31 percent on dividends, the statutory maximum long-term capital gains tax rate on capital gains distributions, and an effective tax rate of 10 percent on undistributed capital gains. 
Table 4: Pretax Returns, After-tax Returns, and Embedded Capital Gains: 20 Largest Equity Mutual Funds, 1998

\begin{tabular}{|l|l|l|l|l|l|l|l|l|}
\hline Fund Name & $\begin{array}{l}\text { Assets } \\
(\$ \mathrm{~B})\end{array}$ & $\begin{array}{l}\text { Pretax } \\
\text { Return }\end{array}$ & $\begin{array}{l}\text { Undistributed } \\
\text { Appreciation }\end{array}$ & Dividends & $\begin{array}{l}\text { Realized } \\
\text { Capital } \\
\text { Gains }\end{array}$ & $\begin{array}{l}\text { Tax } \\
\text { Burden }\end{array}$ & $\begin{array}{l}\text { After- } \\
\text { Tax } \\
\text { Return }\end{array}$ & $\begin{array}{l}\text { Unrealized } \\
\text { Capital Gains/ } \\
\text { Asset Value }\end{array}$ \\
\hline Fidelity Magellan* & 83.6 & 32.9 & 26.8 & 0.7 & 5.4 & 4.0 & 28.9 & $44 \%$ \\
\hline Vanguard Index 500 & 69.5 & 28.5 & 26.5 & 1.5 & 0.5 & 3.2 & 25.2 & $46 \%$ \\
\hline Washington Mutual Investors & 51.8 & 19.0 & 8.4 & 2.0 & 8.6 & 3.2 & 15.8 & $35 \%$ \\
\hline $\begin{array}{l}\text { Investment Company of } \\
\text { America }\end{array}$ & 48.5 & 22.2 & 10.0 & 1.8 & 10.4 & 3.6 & 18.6 & $42 \%$ \\
\hline Vanguard Windsor II & 30.9 & 15.9 & 4.4 & 2.2 & 9.3 & 3.1 & 12.7 & $27 \%$ \\
\hline $\begin{array}{l}\text { American Century/ 20 } \\
\text { Century Ultra }\end{array}$ & 27.2 & 33.8 & 22.4 & 0.0 & 11.4 & 4.5 & 29.3 & $31 \%$ \\
\hline Janus & 25.5 & 38.8 & 35.2 & 0.3 & 3.3 & 4.3 & 34.5 & $26 \%$ \\
\hline $\begin{array}{l}\text { Fidelity Advisors Growth } \\
\text { Opportunity }\end{array}$ & 24.8 & 23.6 & 18.4 & 0.8 & 4.4 & 3.0 & 20.6 & $33 \%$ \\
\hline Fidelity Equity-Income & 23.7 & 12.2 & 6.0 & 1.6 & 4.6 & 2.0 & 10.1 & $36 \%$ \\
\hline Putnam Growth \& Income A & 20.3 & 14.9 & 4.8 & 2.4 & 7.7 & 2.8 & 12.2 & $19 \%$ \\
\hline Fidelity Blue-Chip Growth & 19.9 & 33.2 & 27.7 & 0.3 & 5.2 & 4.0 & 29.2 & $37 \%$ \\
\hline Fidelity Equity-Income II & 19.5 & 22.1 & 11.1 & 1.2 & 9.8 & 3.5 & 18.7 & $35 \%$ \\
\hline $\begin{array}{l}\text { MSDW Dividend Growth } \\
\text { Securities }\end{array}$ & 18.5 & 17.6 & 12.9 & 1.4 & 3.3 & 2.4 & 15.2 & $53 \%$ \\
\hline Growth Fund of America & 16.2 & 31.5 & 19.2 & 0.5 & 11.8 & 4.4 & 27.1 & $44 \%$ \\
\hline Putnam Growth \& Income B & 16.1 & 14.2 & 4.8 & 1.6 & 7.8 & 2.5 & 11.6 & $20 \%$ \\
\hline Janus Twenty & 15.8 & 73.4 & 71.9 & 0.5 & 1.0 & 7.5 & 65.9 & $39 \%$ \\
\hline AIM Constellation A & 14.3 & 18.6 & 15.7 & 0.0 & 2.9 & 2.2 & 16.5 & $38 \%$ \\
\hline Putnam Voyager A & 13.9 & 23.4 & 15.1 & 0.0 & 8.3 & 3.2 & 20.2 & $37 \%$ \\
\hline T Rowe Price Equity-Income & 13.5 & 9.0 & 1.0 & 2.3 & 5.7 & 2.1 & 6.9 & $24 \%$ \\
\hline Fundamental Investors & 12.7 & 16.5 & 5.5 & 1.5 & 9.5 & 2.9 & 13.6 & $25 \%$ \\
\hline Vanguard US Growth & 12.3 & 39.3 & 30.6 & 0.7 & 8.0 & 5.1 & 34.3 & $44 \%$ \\
\hline No: Authors & & & & & & & \\
\hline
\end{tabular}

Note: Authors' tabulations based on Morningstar Principia Database. Tax burden calculations assume a marginal tax rate of 31 percent on dividends, the statutory maximum long-term capital gains tax rate on capital gains distributions, and an effective tax rate of 10 percent on undistributed capital gains. The Fidelity Magellan Fund, closed as of the end of 1998 (though now reopened), is not in our sample in that year. 
Table 5: Pretax Returns, After-tax Returns, and Embedded Capital Gains: 20 Largest S\&P 500 Index Mutual Funds, 1998

\begin{tabular}{|l|l|l|l|l|l|l|l|l|}
\hline Fund Name & $\begin{array}{l}\text { Assets } \\
(\$ B)\end{array}$ & $\begin{array}{l}\text { Pretax } \\
\text { Return }\end{array}$ & $\begin{array}{l}\text { Undistributed } \\
\text { Appreciation }\end{array}$ & $\begin{array}{l}\text { Divi- } \\
\text { dends" }\end{array}$ & $\begin{array}{l}\text { Realized } \\
\text { Capital } \\
\text { Gains }\end{array}$ & $\begin{array}{l}\text { Tax } \\
\text { Burden }\end{array}$ & $\begin{array}{l}\text { After- } \\
\text { Tax } \\
\text { Return }\end{array}$ & $\begin{array}{l}\text { Unrealized } \\
\text { Capital Gains/ } \\
\text { Asset Value }\end{array}$ \\
\hline Vanguard Index 500 & 69.54 & 28.5 & 26.5 & 1.5 & 0.5 & 3.2 & 25.2 & $46 \%$ \\
\hline $\begin{array}{l}\text { Fidelity Spartan Market } \\
\text { Index }\end{array}$ & 7.15 & 28.1 & 24.4 & 1.2 & 2.5 & 3.3 & 24.8 & $30 \%$ \\
\hline T. Rowe Price Equity Index & 3.35 & 28.2 & 26.6 & 1.3 & 0.3 & 3.1 & 25.0 & $36 \%$ \\
\hline S Sg A S\&P 500 Index & 2.25 & 26.3 & 12.3 & 1.6 & 12.4 & 5.5 & 20.8 & $28 \%$ \\
\hline Dreyfus S\&P 500 Index & 2.15 & 28.1 & 26.8 & 1.3 & 0.0 & 3.1 & 25.0 & $38 \%$ \\
\hline $\begin{array}{l}\text { BT Investment Equity 500 } \\
\text { Index }\end{array}$ & 0.87 & 28.3 & 24.8 & 1.5 & 2.0 & 3.3 & 25.0 & $54 \%$ \\
\hline MainStay Equity Index A & 0.80 & 27.6 & 25.5 & 0.7 & 1.4 & 3.1 & 24.6 & $38 \%$ \\
\hline $\begin{array}{l}\text { Galaxy II Large Company } \\
\text { Index Retail }\end{array}$ & 0.75 & 28.0 & 25.3 & 1.3 & 1.4 & 3.2 & 24.8 & $43 \%$ \\
\hline Victory Stock Index & 0.71 & 26.4 & 13.6 & 1.9 & 10.9 & 4.2 & 22.2 & $21 \%$ \\
\hline Stagecoach Equity Index A & 0.61 & 27.4 & 21.0 & 1.0 & 5.4 & 3.5 & 23.9 & $70 \%$ \\
\hline OneGroup Equity Index B & 0.41 & 26.5 & 22.2 & 0.3 & 4.0 & 3.1 & 23.4 & $36 \%$ \\
\hline Pegasus Equity Index A & 0.32 & 27.5 & 18.9 & 0.9 & 7.7 & 3.7 & 23.8 & $37 \%$ \\
\hline OneGroup Equily Index A & 0.27 & 27.4 & 22.3 & 1.1 & 4.0 & 3.4 & 24.0 & $34 \%$ \\
\hline Munder Index 500 A & 0.25 & 27.8 & 25.4 & 1.3 & 1.1 & 3.2 & 24.6 & $35 \%$ \\
\hline Wachovia Equity Index A & 0.14 & 27.6 & 24.3 & 1.3 & 2.0 & 3.3 & 24.3 & $31 \%$ \\
\hline Firstar Equity Index Retail & 0.13 & 28.3 & 26.3 & 1.3 & 0.7 & 3.2 & 25.1 & $50 \%$ \\
\hline $\begin{array}{l}\text { California Investment S\&P } \\
\text { 500 Index }\end{array}$ & 0.13 & 28.3 & 23.8 & 1.8 & 2.7 & 3.5 & 24.8 & $39 \%$ \\
\hline First American Equity Idx A & 0.07 & 28.0 & 24.6 & 1.2 & 2.2 & 3.3 & 24.7 & $36 \%$ \\
\hline First American Equity Idx B & 0.06 & 27.1 & 24.4 & 0.4 & 2.3 & 3.0 & 24.0 & $39 \%$ \\
\hline $\begin{array}{l}\text { Black Rock Index Equity } \\
\text { Investors A }\end{array}$ & 0.05 & 27.9 & 26.9 & 0.7 & 0.3 & 3.0 & 24.9 & $38 \%$ \\
\hline Note: Auth & & & & & & & & \\
\hline
\end{tabular}

Note: Authors' tabulations based on Morningstar Principia Database. Tax burden calculations assume a marginal tax rate of 31 percent on dividends, the statutory maximum long-term capital gains tax rate on capital gains distributions, and an effective tax rate of 10 percent on undistributed capital gains. 
Table 6: Linear Regressions for Persistence of Mutual Fund Returns, Pre-tax and Post-tax Basis

\begin{tabular}{|c|c|c|c|c|c|c|}
\hline & \multicolumn{3}{|c|}{ Relative Return Measures } & \multicolumn{3}{|c|}{$\begin{array}{l}\text { One-Factor Risk-Adjusted Return } \\
\text { Measures }\end{array}$} \\
\hline & Pretax & $\begin{array}{l}\text { After- } \\
\text { Tax }\end{array}$ & $\begin{array}{l}\text { Tax } \\
\text { Burden }\end{array}$ & Pretax & $\begin{array}{l}\text { After- } \\
\text { Tax }\end{array}$ & $\begin{array}{l}\text { Tax } \\
\text { Burden }\end{array}$ \\
\hline \multicolumn{7}{|c|}{ Unweighted Results } \\
\hline $\begin{array}{l}\text { Lagged } \\
\text { Retum }\end{array}$ & $\begin{array}{l}0.269 \\
(0.017)\end{array}$ & $\begin{array}{l}0.278 \\
(0.017)\end{array}$ & $\begin{array}{l}0.265 \\
(0.014)\end{array}$ & $\begin{array}{l}0.296 \\
(0.016)\end{array}$ & $\begin{array}{l}0.298 \\
(0.016)\end{array}$ & $\begin{array}{l}0.277 \\
(0.016)\end{array}$ \\
\hline R2 & 0.211 & 0.262 & 0.406 & 0.140 & 0.133 & 0.199 \\
\hline \multicolumn{7}{|c|}{ Results Weighting Funds by Net Assets } \\
\hline $\begin{array}{l}\text { Lagged } \\
\text { Return }\end{array}$ & $\begin{array}{l}0.367 \\
(0.019)\end{array}$ & $\begin{array}{l}0.369 \\
(0.019)\end{array}$ & $\begin{array}{l}0.389 \\
(0.015)\end{array}$ & $\begin{array}{l}0.404 \\
(0.018)\end{array}$ & $\begin{array}{l}0.396 \\
(0.018)\end{array}$ & $\begin{array}{l}0.427 \\
(0.016)\end{array}$ \\
\hline R2 & 0.153 & 0.209 & 0.503 & 0.123 & $0.1 \overline{17}$ & 0.220 \\
\hline
\end{tabular}

Notes: Estimates based on relative return measures use 5866 fund-year observations; estimates based on risk-adjusted return measures use 4389 fund-year observations. All regressions include year dummies. Standard errors, shown in parentheses, are corrected for clustering. 
Table 7: Regression Estimates of the Determinants of Mutual Fund Tax Burdens

\begin{tabular}{|c|c|c|c|c|c|c|c|}
\hline Variable & Mean & \multicolumn{3}{|c|}{ Unweighted } & \multicolumn{3}{|c|}{ Asset-Weighted } \\
\hline Constant & & $\begin{array}{l}1.014 \\
(0.122)\end{array}$ & $\begin{array}{l}1.352 \\
(0.114)\end{array}$ & $\begin{array}{l}1.075 \\
(0.127)\end{array}$ & $\begin{array}{l}1.257 \\
(0.192)\end{array}$ & $\begin{array}{l}1.513 \\
(0.154)\end{array}$ & $\begin{array}{l}1.112 \\
(0.196)\end{array}$ \\
\hline $\begin{array}{l}\text { Tax Burden } \\
\text { Year t-1 }\end{array}$ & 3.224 & $\begin{array}{l}0.211 \\
(0.020)\end{array}$ & $\begin{array}{l}0.245 \\
(0.028)\end{array}$ & $\begin{array}{l}0.189 \\
(0.021)\end{array}$ & $\begin{array}{l}0.200 \\
(0.040)\end{array}$ & $\begin{array}{l}0.181 \\
(0.035)\end{array}$ & $\begin{array}{l}0.145 \\
(0.038)\end{array}$ \\
\hline $\begin{array}{l}\text { Tax Burden } \\
\text { Year } \mathrm{t}-2\end{array}$ & 2.908 & $\begin{array}{l}0.122 \\
(0.022)\end{array}$ & $\begin{array}{l}0.092 \\
(0.019)\end{array}$ & $\begin{array}{l}0.112 \\
(0.021)\end{array}$ & $\begin{array}{l}0.137 \\
(0.043) \\
\end{array}$ & $\begin{array}{l}0.088 \\
(0.036) \\
\end{array}$ & $\begin{array}{l}0.097 \\
(0.037) \\
\end{array}$ \\
\hline Turnover & 0.790 & $\begin{array}{l}0.431 \\
(0.053)\end{array}$ & $\begin{array}{l}0.448 \\
(0.058)\end{array}$ & $\begin{array}{l}0.448 \\
(0.054)\end{array}$ & $\begin{array}{l}0.692 \\
(0.115)\end{array}$ & $\begin{array}{l}0.745 \\
(0.110)\end{array}$ & $\begin{array}{l}0.753 \\
(0.113)\end{array}$ \\
\hline $\begin{array}{l}\text { Lagged } \\
\text { Turnover }\end{array}$ & 0.801 & $\begin{array}{l}-0.268 \\
(0.043) \\
\end{array}$ & $\begin{array}{l}-0.289 \\
(0.043) \\
\end{array}$ & $\begin{array}{l}-0.244 \\
(0.044) \\
\end{array}$ & $\begin{array}{l}-0.472 \\
(0.096)\end{array}$ & $\begin{array}{l}-0.471 \\
(0.090)\end{array}$ & $\begin{array}{l}-0.438 \\
(0.092)\end{array}$ \\
\hline $\begin{array}{l}\text { Return } \\
\text { Yeart }\end{array}$ & 18.079 & $\begin{array}{l}0.113 \\
(0.020)\end{array}$ & $\begin{array}{l}0.117 \\
(0.002)\end{array}$ & $\begin{array}{l}0.114 \\
(0.020\end{array}$ & $\begin{array}{l}0.106 \\
(0.029)\end{array}$ & $\begin{array}{l}0.110 \\
(0.003)\end{array}$ & $\begin{array}{l}0.110 \\
(0.030)\end{array}$ \\
\hline $\begin{array}{l}\text { Return } \\
\text { Year t-1 }\end{array}$ & 16.818 & $\begin{array}{l}-0.034 \\
(0.003)\end{array}$ & $\begin{array}{l}-0.035 \\
(0.004)\end{array}$ & $\begin{array}{l}-0.032 \\
(0.004)\end{array}$ & $\begin{array}{l}-0.018 \\
(0.008)\end{array}$ & $\begin{array}{l}-0.016 \\
(0.007)\end{array}$ & $\begin{array}{l}-0.015 \\
(0.007)\end{array}$ \\
\hline $\begin{array}{l}\text { Return } \\
\text { Year } \mathrm{t}-2\end{array}$ & 14.715 & $\begin{array}{l}-0.026 \\
(0.004)\end{array}$ & $\begin{array}{l}-0.018 \\
(0.003)\end{array}$ & $\begin{array}{l}-0.026 \\
(0.004)\end{array}$ & $\begin{array}{l}-0.031 \\
(0.007)\end{array}$ & $\begin{array}{l}-0.021 \\
(0.005)\end{array}$ & $\begin{array}{l}-0.028 \\
(0.007)\end{array}$ \\
\hline $\begin{array}{l}\text { New } \\
\text { Manager } \\
\text { This Year? }\end{array}$ & 0.060 & $\begin{array}{l}0.243 \\
(0.079)\end{array}$ & $\begin{array}{l}0.283 \\
(0.079)\end{array}$ & $\begin{array}{l}0.263 \\
(0.078)\end{array}$ & $\begin{array}{l}0.453 \\
(0.160)\end{array}$ & $\begin{array}{l}0.439 \\
(0.158)\end{array}$ & $\begin{array}{l}0.438 \\
(0.147)\end{array}$ \\
\hline $\begin{array}{l}\text { New } \\
\text { Manager } \\
\text { Last Year? }\end{array}$ & 0.096 & $\begin{array}{l}0.124 \\
(0.061)\end{array}$ & $\begin{array}{l}0.161 \\
(0.060)\end{array}$ & $\begin{array}{l}0.145 \\
(0.061)\end{array}$ & $\begin{array}{l}0.011 \\
(0.085)\end{array}$ & $\begin{array}{l}0.050 \\
(0.076)\end{array}$ & $\begin{array}{l}0.045 \\
(0.079)\end{array}$ \\
\hline $\begin{array}{l}\text { Expense } \\
\text { Ratio }\end{array}$ & 1.272 & $\begin{array}{l}-0.061 \\
(0.062)\end{array}$ & $\begin{array}{l}-0.101 \\
(0.059)\end{array}$ & $\begin{array}{l}-0.083 \\
(0.068)\end{array}$ & $\begin{array}{l}-0.017 \\
(0.071)\end{array}$ & $\begin{array}{l}-0.080 \\
(0.050)\end{array}$ & $\begin{array}{l}-0.079 \\
(0.052)\end{array}$ \\
\hline $\begin{array}{l}8<=\text { Fund } \\
\text { Age }<16\end{array}$ & 0.354 & $\begin{array}{l}-0.032 \\
(0.040)\end{array}$ & $\begin{array}{l}-0.048 \\
(0.036)\end{array}$ & $\begin{array}{l}-0.060 \\
(0.040)\end{array}$ & $\begin{array}{l}-0.137 \\
(0.056)\end{array}$ & $\begin{array}{l}-0.165 \\
(0.056)\end{array}$ & $\begin{array}{l}-0.171 \\
(0.060)\end{array}$ \\
\hline $\begin{array}{l}16<=\text { Fund } \\
\text { Age }\end{array}$ & 0.313 & $\begin{array}{l}-0.006 \\
(0.044)\end{array}$ & $\begin{array}{l}0.021 \\
(0.042)\end{array}$ & $\begin{array}{l}-0.014 \\
(0.045)\end{array}$ & $\begin{array}{l}0.023 \\
(0.061)\end{array}$ & $\begin{array}{l}-0.003 \\
(0.058)\end{array}$ & $\begin{array}{l}-0.014 \\
(0.065)\end{array}$ \\
\hline $\begin{array}{l}\text { Index Fund } \\
\text { Indicator }\end{array}$ & 0.032 & & $\begin{array}{l}-0.312 \\
(0.076)\end{array}$ & $\begin{array}{l}-0.331 \\
(0.079)\end{array}$ & & $\begin{array}{l}-0.469 \\
(0.114)\end{array}$ & $\begin{array}{l}-0.457 \\
(0.119)\end{array}$ \\
\hline $\begin{array}{l}\text { Tax- } \\
\text { Managed } \\
\text { Indicator }\end{array}$ & 0.001 & & $\begin{array}{l}-0.742 \\
(0.071)\end{array}$ & $\begin{array}{l}-0.750 \\
(0.072)\end{array}$ & & $\begin{array}{l}-0.382 \\
(0.110)\end{array}$ & $\begin{array}{l}-0.428 \\
(0.119)\end{array}$ \\
\hline $\begin{array}{l}\text { Inflows at } \\
t-1\left(\times 10^{-2}\right)\end{array}$ & 18.769 & $\begin{array}{l}-0.139 \\
(0.029)\end{array}$ & $\begin{array}{l}-0.165 \\
(0.029)\end{array}$ & $\begin{array}{l}-0.138 \\
(0.030)\end{array}$ & $\begin{array}{l}-0.321 \\
(0.061)\end{array}$ & $\begin{array}{l}-0.311 \\
(0.051)\end{array}$ & $\begin{array}{l}-0.268 \\
(0.053)\end{array}$ \\
\hline $\begin{array}{l}\text { Inflows at } \\
\text { t- } 2\left(\begin{array}{cc} & 10^{-2}\end{array}\right)\end{array}$ & 27.635 & $\begin{array}{l}-0.015 \\
(0.020)\end{array}$ & $\begin{array}{l}-0.021 \\
(0.021)\end{array}$ & $\begin{array}{l}-0.014 \\
(0.021)\end{array}$ & $\begin{array}{l}0.023 \\
(0.038)\end{array}$ & $\begin{array}{l}-0.028 \\
(0.034)\end{array}$ & $\begin{array}{l}-0.004 \\
(0.035)\end{array}$ \\
\hline $\begin{array}{l}\text { Inflows at } \\
\mathrm{t}-3\left(\times 10^{-2}\right)\end{array}$ & 48.634 & $\begin{array}{l}-0.024 \\
(0.013)\end{array}$ & $\begin{array}{l}-0.022 \\
(0.014)\end{array}$ & $\begin{array}{l}-0.025 \\
(0.013)\end{array}$ & $\begin{array}{l}-0.025 \\
(0.016)\end{array}$ & $\begin{array}{l}-0.025 \\
(0.016)\end{array}$ & $\begin{array}{l}-0.030 \\
(0.016)\end{array}$ \\
\hline $\begin{array}{l}\text { Unrealized } \\
\text { Gains (t-1) }\end{array}$ & 20.710 & $\begin{array}{l}0.006 \\
(0.002)\end{array}$ & & $\begin{array}{l}0.008 \\
(0.002)\end{array}$ & $\begin{array}{l}0.002 \\
(0.003\end{array}$ & & $\begin{array}{l}0.006 \\
(0.003)\end{array}$ \\
\hline $\begin{array}{l}\text { Fund Style } \\
\text { Indicators? }\end{array}$ & & No & Yes & Yes & No & Yes & Yes \\
\hline R2 & & 0.815 & 0.804 & 0.819 & 0.871 & 0.872 & 0.879 \\
\hline $\mathrm{N}$ & & 2752 & 3313 & 2752 & 2752 & 3313 & 2752 \\
\hline
\end{tabular}

Notes: All estimates are based on 2752 fund-year observations for the period 1993-1998. All equations include indicator variables for each year, as well as indicator variables for fund styles. Standard errors, shown in parentheses, are corrected for clustering. 
Table 8: Linear Models for Mutual Fund Inflows and Return Measures

\begin{tabular}{|c|c|c|c|c|c|c|}
\hline Variable (lag) & \multicolumn{3}{|c|}{ Returns Relative to S\&P 500} & \multicolumn{3}{|c|}{ One-Factor Risk-Adjusted Returns } \\
\hline \multicolumn{7}{|l|}{ Unweighted } \\
\hline Pretax Return & $\begin{array}{l}2.918 \\
(0.192) \\
\end{array}$ & & $\begin{array}{l}3.548 \\
(0.226) \\
\end{array}$ & $\begin{array}{l}1.608 \\
(0.130) \\
\end{array}$ & & $\begin{array}{l}.005 \\
(0.161) \\
\end{array}$ \\
\hline After-tax Retum & & $\begin{array}{l}3.334 \\
(0.211)\end{array}$ & & & $\begin{array}{l}1.805 \\
(0.142)\end{array}$ & \\
\hline Tax Burden & & & $\begin{array}{l}-5.526 \\
(1.232)\end{array}$ & & & $\begin{array}{l}-4.114 \\
(1.102)\end{array}$ \\
\hline R2 & 0.106 & 0.110 & 0.111 & 0.072 & 0.075 & 0.076 \\
\hline \multicolumn{7}{|c|}{ Results Weighted by Fund Net Assets } \\
\hline Pretax Return & \begin{tabular}{|l|}
2.060 \\
$(0.111)$
\end{tabular} & & $\begin{array}{l}2.963 \\
(0.166)\end{array}$ & $\begin{array}{l}1.189 \\
(0.083)\end{array}$ & & $\begin{array}{l}1.993 \\
(0.136) \\
\end{array}$ \\
\hline After-tax Retum & & $\begin{array}{l}2.415 \\
(0.127)\end{array}$ & & & $\begin{array}{l}1.390 \\
(0.093)\end{array}$ & \\
\hline Tax Burden & . & & $\begin{array}{l}-8.691 \\
(0.849)\end{array}$ & $\because$ & & $\begin{array}{l}-8.267 \\
(0.999) \\
\end{array}$ \\
\hline $\mathrm{R} 2$ & 0.176 & 0.197 & 0.219 & 0.117 & 0.131 & 0.161 \\
\hline
\end{tabular}

Notes: Estimates based on relative return measures use 5866 fund-year observations; estimates based on risk-adjusted return measures use 4389 fund-year observations. All regressions include year dummies. Standard errors, shown in parentheses, are corrected for clustering. 
Table 9: Mutual Fund Inflows and Return Measures - Spline Regressions

\begin{tabular}{|c|c|c|c|c|c|c|}
\hline \multirow{2}{*}{$\begin{array}{l}\text { Variable } \\
\text { Unweighted }\end{array}$} & \multicolumn{3}{|c|}{ Returns Relative to S\&P 500} & \multicolumn{3}{|c|}{ One-Factor Risk-Adjusted Retums } \\
\hline & & & & & & \\
\hline $\begin{array}{l}\text { Lagged Return } \\
\text { Percentiles: }\end{array}$ & Pretax & After-tax & Pretax & Pretax & After-tax & Pretax \\
\hline$<20$ & $\begin{array}{l}1.242 \\
(0.280)\end{array}$ & $\begin{array}{l}1.453 \\
(0.263)\end{array}$ & $\begin{array}{l}1.873 \\
(0.305)\end{array}$ & $\begin{array}{l}0.694 \\
(0.159)\end{array}$ & $\begin{array}{l}0.897 \\
(0.179)\end{array}$ & $\begin{array}{l}1.068 \\
(0.177)\end{array}$ \\
\hline $20^{\text {th }}-40^{\text {th }}$ & $\begin{array}{l}0.882 \\
(0.537)\end{array}$ & $\begin{array}{l}1.963 \\
(0.608)\end{array}$ & $\begin{array}{l}1.438 \\
(0.547)\end{array}$ & $\begin{array}{l}0.960 \\
(0.702)\end{array}$ & $\begin{array}{l}0.094 \\
(0.782)\end{array}$ & $\begin{array}{l}1.318 \\
(0.688)\end{array}$ \\
\hline $40^{\mathrm{lh}}-60^{\mathrm{th}}$ & $\begin{array}{l}6.330 \\
(0.891)\end{array}$ & $\begin{array}{l}6.613 \\
(1.024)\end{array}$ & $\begin{array}{l}6.899 \\
(0.904)\end{array}$ & $\begin{array}{l}4.144 \\
(1.285)\end{array}$ & $\begin{array}{l}5.565 \\
(1.336) \\
\end{array}$ & $\begin{array}{l}4.340 \\
(1.289)\end{array}$ \\
\hline $60^{\text {th }}-80^{\text {th }}$ & $\begin{array}{l}4.000 \\
(1.215)\end{array}$ & $\begin{array}{l}4.151 \\
(1.212)\end{array}$ & $\begin{array}{l}4.366 \\
(1.211)\end{array}$ & $\begin{array}{l}3.105 \\
(1.287)\end{array}$ & $\begin{array}{l}3.251 \\
(1.400)\end{array}$ & $\begin{array}{l}3.417 \\
(1.304) \\
\end{array}$ \\
\hline $80^{\text {th }}-95^{\text {th }}$ & $\begin{array}{l}6.008 \\
(1.145)\end{array}$ & $\begin{array}{l}6.099 \\
(1.178)\end{array}$ & $\begin{array}{l}6.623 \\
(1.143)\end{array}$ & $\begin{array}{l}3.569 \\
(0.826)\end{array}$ & $\begin{array}{l}4.141 \\
(0.879)\end{array}$ & $\begin{array}{l}3.882 \\
(0.808)\end{array}$ \\
\hline$>95^{1 \mathrm{~h}}$ & $\begin{array}{l}2.085 \\
(1.459)\end{array}$ & $\begin{array}{l}2.592 \\
(1.746)\end{array}$ & $\begin{array}{l}2.594 \\
(1.486)\end{array}$ & $\begin{array}{l}0.412 \\
(1.006)\end{array}$ & $\begin{array}{l}0.168 \\
(0.951)\end{array}$ & $\begin{array}{l}0.670 \\
(1.010)\end{array}$ \\
\hline Tax Burden & & & $\begin{array}{l}-4.969 \\
(1.208)\end{array}$ & & & $\begin{array}{l}-3.460 \\
(1.083)\end{array}$ \\
\hline R2 & 0.127 & 0.127 & 0.132 & 0.090 & 0.094 & 0.093 \\
\hline Weighted by Fu & Net Asse & & & & & \\
\hline $\begin{array}{l}\text { Lagged Return } \\
\text { Percentiles: }\end{array}$ & Pretax & After-tax & Pretax & Pretax & After-tax & Pretax \\
\hline$<20$ & $\begin{array}{l}1.306 \\
(0.156) \\
\end{array}$ & $\begin{array}{l}1.455 \\
(0.165) \\
\end{array}$ & $\begin{array}{l}2.478 \\
(0.169) \\
\end{array}$ & $\begin{array}{l}0.576 \\
(0.113) \\
\end{array}$ & $\begin{array}{l}0.623 \\
(0.128) \\
\end{array}$ & $\begin{array}{l}1.425 \\
(0.145)\end{array}$ \\
\hline $20^{\text {th }}-40^{\text {th }}$ & $\begin{array}{l}0.749 \\
(0.484)\end{array}$ & $\begin{array}{l}1.649 \\
(0.431)\end{array}$ & $\begin{array}{l}1.226 \\
(0.443)\end{array}$ & $\begin{array}{l}0.079 \\
(0.616)\end{array}$ & $\begin{array}{l}0.371 \\
(0.632)\end{array}$ & $\begin{array}{l}0.779 \\
(0.595)\end{array}$ \\
\hline $40^{\text {th }}-60^{\text {th }}$ & $\begin{array}{l}2.984 \\
(0.798) \\
\end{array}$ & $\begin{array}{l}2.402 \\
(0.915)\end{array}$ & $\begin{array}{l}4.030 \\
(0.799)\end{array}$ & $\begin{array}{l}4.688 \\
(1.132)\end{array}$ & $\begin{array}{l}4.068 \\
(1.055)\end{array}$ & $\begin{array}{l}4.979 \\
(0.853)\end{array}$ \\
\hline $60^{\mathrm{th}}-80^{\mathrm{th}}$ & $\begin{array}{l}3.336 \\
(0.859) \\
\end{array}$ & $\begin{array}{l}4.594 \\
(0.975) \\
\end{array}$ & $\begin{array}{l}3.982 \\
(0.806) \\
\end{array}$ & $\begin{array}{l}0.625 \\
(0.844) \\
\end{array}$ & $\begin{array}{l}2.043 \\
(0.903) \\
\end{array}$ & $\begin{array}{l}1.782 \\
(0.746) \\
\end{array}$ \\
\hline $80^{\text {th }}-95^{\text {th }}$ & $\begin{array}{l}3.549 \\
(0.645)\end{array}$ & $\begin{array}{l}4.273 \\
(0.707)\end{array}$ & $\begin{array}{l}4.646 \\
(0.610)\end{array}$ & $\begin{array}{l}3.126 \\
(0.573)\end{array}$ & $\begin{array}{l}3.294 \\
(0.654)\end{array}$ & $\begin{array}{l}3.856 \\
(0.576)\end{array}$ \\
\hline$>95^{\text {th }}$ & $\begin{array}{l}1.597 \\
(1.055)\end{array}$ & $\begin{array}{l}1.566 \\
(1.152)\end{array}$ & $\begin{array}{l}2.540 \\
(1.023)\end{array}$ & $\begin{array}{l}0.462 \\
(1.057)\end{array}$ & $\begin{array}{l}0.397 \\
(1.093)\end{array}$ & $\begin{array}{l}1.197 \\
(1.041)\end{array}$ \\
\hline Tax Burden & & & $\begin{array}{l}-8.724 \\
(0.779)\end{array}$ & & & $\begin{array}{l}-8.045 \\
(0.907)\end{array}$ \\
\hline $\mathrm{R} 2$ & 0.196 & 0.220 & 0.239 & 0.147 & 0.164 & 0.188 \\
\hline
\end{tabular}

Notes: Estimates based on relative return measures use 5866 fund-year observations; estimates based on risk-adjusted return measures use 4389 fund-year observations. All regressions include year dummies. Standard errors, shown in parentheses, are corrected for clustering. 
Table 10: Regressions with Additional Controls - Unweighted Linear Models

\begin{tabular}{|c|c|c|c|c|c|}
\hline Variable & Mean & Model 1 & Model 2 & Model 3 & Model 4 \\
\hline $\begin{array}{l}\text { Pretax } \\
\text { Return t-1 }\end{array}$ & & $\begin{array}{l}1.989 \\
(0.171)\end{array}$ & $\begin{array}{l}2.579 \\
(0.232)\end{array}$ & $\begin{array}{l}2.597 \\
(0.236) \\
\end{array}$ & $\begin{array}{l}1.985 \\
(0.233) \\
\end{array}$ \\
\hline $\begin{array}{l}\text { Tax Burden } \\
\mathrm{t}-1\end{array}$ & & & $\begin{array}{l}-4.935 \\
(1.024) \\
\end{array}$ & $\begin{array}{l}-4.254 \\
(1.080) \\
\end{array}$ & $\begin{array}{l}-1.773 \\
(1.066) \\
\end{array}$ \\
\hline $\begin{array}{l}\text { Unrealized } \\
\text { Capital Gain } \\
\text { /Asset Value }\end{array}$ & & & & $\begin{array}{l}-0.213 \\
(0.100)\end{array}$ & $\begin{array}{l}-0.087 \\
(0.058)\end{array}$ \\
\hline $\begin{array}{l}\text { Lagged } \\
\text { Inflow }\end{array}$ & 32.646 & & & & $\begin{array}{l}0.179 \\
(0.023)\end{array}$ \\
\hline $\begin{array}{l}8<\text { Age }<= \\
16\end{array}$ & 0.267 & $\begin{array}{l}-17.603 \\
(2.023) \\
\end{array}$ & $\begin{array}{l}-16.553 \\
(1.985) \\
\end{array}$ & $\begin{array}{l}-15.777 \\
(2.001) \\
\end{array}$ & $\begin{array}{l}-9.211 \\
(1.849) \\
\end{array}$ \\
\hline $16<$ Age & 0.227 & $\begin{array}{r}-17.529 \\
(1.850) \\
\end{array}$ & $\begin{array}{l}-15.297 \\
(1.821)\end{array}$ & $\begin{array}{l}-14.658 \\
(1.939) \\
\end{array}$ & $\begin{array}{l}-7.659 \\
(1.783) \\
\end{array}$ \\
\hline Large Blend & 0.257 & $\begin{array}{l}2.381 \\
(3.050)\end{array}$ & $\begin{array}{l}1.645 \\
(3.011)\end{array}$ & $\begin{array}{l}1.865 \\
(3.003)\end{array}$ & $\begin{array}{l}0.844 \\
(2.871)\end{array}$ \\
\hline $\begin{array}{l}\text { Large } \\
\text { Growth }\end{array}$ & 0.103 & $\begin{array}{l}3.347 \\
(5.043)\end{array}$ & $\begin{array}{l}2.336 \\
(5.050)\end{array}$ & $\begin{array}{l}3.278 \\
(5.073)\end{array}$ & $\begin{array}{l}1.495 \\
(4.903)\end{array}$ \\
\hline $\begin{array}{l}\text { Mid-Cap } \\
\text { Value }\end{array}$ & 0.086 & $\begin{array}{l}-0.218 \\
(3.521)\end{array}$ & $\begin{array}{l}-0.506 \\
(3.477)\end{array}$ & $\begin{array}{l}-0.505 \\
(3.459)\end{array}$ & $\begin{array}{l}0.394 \\
(3.161)\end{array}$ \\
\hline $\begin{array}{l}\text { Mid-Cap } \\
\text { Blend } \\
\end{array}$ & 0.089 & $\begin{array}{l}8.258 \\
(4.216) \\
\end{array}$ & $\begin{array}{l}7.142 \\
(4.171) \\
\end{array}$ & $\begin{array}{l}7.663 \\
(4.184) \\
\end{array}$ & $\begin{array}{l}5.378 \\
(3.957) \\
\end{array}$ \\
\hline $\begin{array}{l}\text { Mid-Cap } \\
\text { Growth }\end{array}$ & 0.102 & $\begin{array}{l}11.753 \\
(4.999) \\
\end{array}$ & $\begin{array}{l}9.824 \\
(4.911)\end{array}$ & $\begin{array}{l}11.200 \\
(4.952)\end{array}$ & $\begin{array}{l}8.256 \\
(4.714)\end{array}$ \\
\hline Small Value & 0.076 & $\begin{array}{l}10.728 \\
(4.113)\end{array}$ & $\begin{array}{l}10.468 \\
(4.042)\end{array}$ & $\begin{array}{l}10.602 \\
(4.029) \\
\end{array}$ & $\begin{array}{l}9.789 \\
(3.660) \\
\end{array}$ \\
\hline Small Blend & 0.042 & $\begin{array}{l}15.414 \\
(5.413) \\
\end{array}$ & $\begin{array}{l}13.979 \\
(5.412)\end{array}$ & $\begin{array}{l}14.696 \\
(5.350) \\
\end{array}$ & $\begin{array}{l}9.450 \\
(4.716) \\
\end{array}$ \\
\hline $\begin{array}{l}\text { Small } \\
\text { Growth }\end{array}$ & 0.052 & $\begin{array}{l}18.146 \\
(5.506)\end{array}$ & $\begin{array}{l}15.997 \\
(5.373)\end{array}$ & $\begin{array}{l}17.255 \\
(5.380) \\
\end{array}$ & $\begin{array}{l}13.961 \\
(5.260) \\
\end{array}$ \\
\hline $\begin{array}{l}\text { Log Fund } \\
\text { Size t-1 }\end{array}$ & 5.065 & $\begin{array}{l}-6.012 \\
(0.729)\end{array}$ & $\begin{array}{l}-6.276 \\
(0.729)\end{array}$ & $\begin{array}{l}-6.198 \\
(0.724)\end{array}$ & $\begin{array}{l}-6.307 \\
(0.674)\end{array}$ \\
\hline $\begin{array}{l}\text { Expense } \\
\text { Ratio t-1 }\end{array}$ & 1.364 & $\begin{array}{l}-0.667 \\
(2.293)\end{array}$ & $\begin{array}{l}-1.422 \\
(2.324)\end{array}$ & $\begin{array}{l}-2.292 \\
(2.351)\end{array}$ & $\begin{array}{l}-3.304 \\
(2.106)\end{array}$ \\
\hline $\begin{array}{l}\text { Turnover } \\
\text { Ratio t-1 }\end{array}$ & 0.839 & $\begin{array}{l}-1.310 \\
(1.005)\end{array}$ & $\begin{array}{l}0.048 \\
(1.225)\end{array}$ & $\begin{array}{l}-1.109 \\
(1.263)\end{array}$ & $\begin{array}{l}-1.412 \\
(1.313)\end{array}$ \\
\hline $\begin{array}{l}\text { Load } \\
\text { Dummy }\end{array}$ & 0.595 & $\begin{array}{l}7.680 \\
(2.071) \\
\end{array}$ & $\begin{array}{l}8.367 \\
(2.032) \\
\end{array}$ & $\begin{array}{l}8.766 \\
(2.043) \\
\end{array}$ & $\begin{array}{l}6.937 \\
(1.772) \\
\end{array}$ \\
\hline $\begin{array}{l}\text { Median } \\
\text { Market Cap }\end{array}$ & 11.899 & $\begin{array}{l}-0.130 \\
(0.105)\end{array}$ & $\begin{array}{l}-0.161 \\
(0.104)\end{array}$ & $\begin{array}{l}-0.174 \\
(0.103)\end{array}$ & $\begin{array}{l}-0.119 \\
(0.098)\end{array}$ \\
\hline $\begin{array}{l}\text { Price/Book } \\
\text { Ratio } \\
\end{array}$ & 4.951 & $\begin{array}{l}1.414 \\
(0.959)\end{array}$ & $\begin{array}{l}1.499 \\
(0.956)\end{array}$ & $\begin{array}{l}1.764 \\
(0.955)\end{array}$ & $\begin{array}{l}2.072 \\
(0.913)\end{array}$ \\
\hline $\begin{array}{l}\text { Morningstar } \\
\text { Rating }\end{array}$ & 3.103 & $\begin{array}{l}17.432 \\
(1.353) \\
\end{array}$ & $\begin{array}{l}17.262 \\
(1.352) \\
\end{array}$ & $\begin{array}{l}17.076 \\
(1.358)\end{array}$ & $\begin{array}{l}14.126 \\
(1.320) \\
\end{array}$ \\
\hline $\mathrm{R} 2$ & & 0.237 & 0.242 & 0.244 & 0.293 \\
\hline $\mathrm{N}$ & & 4591 & 4591 & 4591 & 4591 \\
\hline
\end{tabular}

Note. All regressions include year dummies. Standard errors, shown in parentheses, are corrected for clustering. 
Table 11: Regressions with Additional Controls -- Linear Models, Weighted by Fund Net Assets

\begin{tabular}{|c|c|c|c|c|c|}
\hline Variable & Mean & Model 1 & Model 2 & Model 3 & Model 4 \\
\hline $\begin{array}{l}\text { Pretax Return } \\
\mathrm{t}-1\end{array}$ & & $\begin{array}{l}1.565 \\
(0.105) \\
\end{array}$ & $\begin{array}{l}2.405 \\
(0.176) \\
\end{array}$ & $\begin{array}{l}2.495 \\
(0.169) \\
\end{array}$ & $\begin{array}{l}1.899 \\
(0.159)\end{array}$ \\
\hline Tax Burden t- 1 & & & $\begin{array}{l}-7.435 \\
(0.893)\end{array}$ & $\begin{array}{l}-6.193 \\
(0.855) \\
\end{array}$ & $\begin{array}{l}-3.792 \\
(0.792) \\
\end{array}$ \\
\hline $\begin{array}{l}\text { Unrealized } \\
\text { Capital Gain } \\
\text { /Asset Value }\end{array}$ & & & & $\begin{array}{l}-0.450 \\
(0.072)\end{array}$ & $\begin{array}{l}-0.241 \\
(0.064)\end{array}$ \\
\hline Lagged Inflow & $\begin{array}{l}21.69 \\
5\end{array}$ & & & & $\begin{array}{l}0.153 \\
(0.022)\end{array}$ \\
\hline $8<$ Age $<=16$ & 0.293 & $\begin{array}{l}-13.748 \\
(2.461) \\
\end{array}$ & $\begin{array}{l}-12.131 \\
(2.303) \\
\end{array}$ & $\begin{array}{l}-10.382 \\
(2.294) \\
\end{array}$ & $\begin{array}{l}-6.319 \\
(1.983)\end{array}$ \\
\hline $16<$ Age & 0.534 & $\begin{array}{l}-16.539 \\
(2.618) \\
\end{array}$ & $\begin{array}{l}-13.566 \\
(2.422) \\
\end{array}$ & $\begin{array}{l}-10.413 \\
(2.381) \\
\end{array}$ & $\begin{array}{l}-6.510 \\
(2.027)\end{array}$ \\
\hline Large Blend & 0.303 & $\begin{array}{l}-1.026 \\
(2.087) \\
\end{array}$ & $\begin{array}{l}-3.016 \\
(2.025) \\
\end{array}$ & $\begin{array}{l}-2.231 \\
(1.749)\end{array}$ & $\begin{array}{l}-2.635 \\
(1.642) \\
\end{array}$ \\
\hline Large Growth & 0.137 & $\begin{array}{l}-0.313 \\
(3.209)\end{array}$ & $\begin{array}{l}-1.512 \\
(2.996) \\
\end{array}$ & $\begin{array}{l}-0.512 \\
(2.917) \\
\end{array}$ & $\begin{array}{l}-1.438 \\
(2.590) \\
\end{array}$ \\
\hline $\begin{array}{l}\text { Mid-Cap } \\
\text { Value } \\
\end{array}$ & 0.048 & $\begin{array}{l}-1.295 \\
(2.277) \\
\end{array}$ & $\begin{array}{l}-0.919 \\
(2.391)\end{array}$ & $\begin{array}{l}-1.178 \\
(2.334)\end{array}$ & $\begin{array}{l}-1.402 \\
(2.100)\end{array}$ \\
\hline $\begin{array}{l}\text { Mid-Cap } \\
\text { Blend }\end{array}$ & 0.061 & $\begin{array}{l}4.900 \\
(2.761) \\
\end{array}$ & $\begin{array}{l}2.013 \\
(2.637) \\
\end{array}$ & $\begin{array}{l}3.698 \\
(2.586)\end{array}$ & $\begin{array}{l}1.533 \\
(2.222) \\
\end{array}$ \\
\hline $\begin{array}{l}\text { Mid-Cap } \\
\text { Growth }\end{array}$ & 0.075 & $\begin{array}{l}10.725 \\
(3.320) \\
\end{array}$ & $\begin{array}{l}6.446 \\
(3.300)\end{array}$ & $\begin{array}{l}8.571 \\
(3.184)\end{array}$ & $\begin{array}{l}5.341 \\
(2.997) \\
\end{array}$ \\
\hline Small Value & 0.021 & $\begin{array}{l}3.974 \\
(2.802) \\
\end{array}$ & $\begin{array}{l}3.714 \\
(2.765) \\
\end{array}$ & $\begin{array}{l}3.768 \\
(2.638) \\
\end{array}$ & \begin{tabular}{|l|}
3.869 \\
$(2.849)$ \\
\end{tabular} \\
\hline $\begin{array}{l}\text { Small } \\
\text { Blend } \\
\end{array}$ & 0.014 & $\begin{array}{l}10.836 \\
(6.170)\end{array}$ & $\begin{array}{l}7.429 \\
(6.015)\end{array}$ & $\begin{array}{l}8.829 \\
(5.660)\end{array}$ & $\begin{array}{l}4.994 \\
(5.127)\end{array}$ \\
\hline Small Growth & 0.018 & $\begin{array}{l}8.723 \\
(4.249)\end{array}$ & $\begin{array}{l}5.089 \\
(4.126) \\
\end{array}$ & $\begin{array}{l}7.525 \\
(3.925)\end{array}$ & $\begin{array}{l}3.772 \\
(3.340)\end{array}$ \\
\hline $\begin{array}{l}\text { Log Fund Size } \\
\mathrm{t}-1\end{array}$ & 8.156 & $\begin{array}{l}-2 . \overline{936} \\
(0.681) \\
\end{array}$ & $\begin{array}{l}-3.684 \\
(0.683) \\
\end{array}$ & $\begin{array}{l}-3.503 \\
(0.645)\end{array}$ & $\begin{array}{l}-3.254 \\
(0.553) \\
\end{array}$ \\
\hline $\begin{array}{l}\text { Expense Ratio } \\
\mathrm{t}-1\end{array}$ & 0.961 & $\begin{array}{l}-0.282 \\
(2.142) \\
\end{array}$ & $\begin{array}{l}-2.161 \\
(2.011) \\
\end{array}$ & $\begin{array}{l}-1.453 \\
(1.854)\end{array}$ & $\begin{array}{l}-2.892 \\
(1.608) \\
\end{array}$ \\
\hline $\begin{array}{l}\text { Turnover } \\
\text { Ratio t-1 } \\
\end{array}$ & 0.690 & $\begin{array}{l}-2.318 \\
(1.387)\end{array}$ & $\begin{array}{l}1.100 \\
(1.354)\end{array}$ & $\begin{array}{l}-1.735 \\
(1.405)\end{array}$ & $\begin{array}{l}-1.863 \\
(1.224)\end{array}$ \\
\hline Load Dummy & 0.572 & $\begin{array}{l}1.376 \\
(1.676)\end{array}$ & $\begin{array}{l}2.055 \\
(1.524) \\
\end{array}$ & $\begin{array}{l}1.998 \\
(1.440)\end{array}$ & $\begin{array}{l}2.284 \\
(1.216)\end{array}$ \\
\hline $\begin{array}{l}\text { Median Market } \\
\text { Cap }\end{array}$ & 17.29 & $\begin{array}{l}-0.075 \\
(0.061) \\
\end{array}$ & $\begin{array}{l}-0.057 \\
(0.066) \\
\end{array}$ & $\begin{array}{l}-0.065 \\
(0.065)\end{array}$ & $\begin{array}{l}-0.053 \\
(0.053) \\
\end{array}$ \\
\hline $\begin{array}{l}\text { Price/Book } \\
\text { Ratio }\end{array}$ & 5.178 & $\begin{array}{l}1.575 \\
(0.883)\end{array}$ & $\begin{array}{l}1.446 \\
(0.877)\end{array}$ & $\begin{array}{l}1.850 \\
(0.826)\end{array}$ & $\begin{array}{l}2.001 \\
(0.756)\end{array}$ \\
\hline $\begin{array}{l}\text { Morningstar } \\
\text { Rating } \\
\end{array}$ & 3.738 & $\begin{array}{l}10.764 \\
(0.956) \\
\end{array}$ & $\begin{array}{l}9.916 \\
(0.908) \\
\end{array}$ & $\begin{array}{l}9.219 \\
(0.872) \\
\end{array}$ & $\begin{array}{l}8.137 \\
(0.877) \\
\end{array}$ \\
\hline R2 & & 0.339 & 0.363 & 0.376 & 0.430 \\
\hline $\mathrm{N}$ & & 4591 & 4591 & 4591 & 4591 \\
\hline
\end{tabular}

Note. All regressions include year dummies. Standard errors, shown in parentheses, are corrected for clustering. 
Table 12: Net Inflow Regressions Using Different Tax Burden Measures Weighted by Fund Net Assets

\begin{tabular}{|l|l|l|}
\hline Independent & Tax Measure Aggregates Short & $\begin{array}{l}\text { Tax Measure Splits Short } \\
\text { Verm and Long Term Gains }\end{array}$ \\
\hline Relative & 2.367 & 2.292 \\
Return t-1 & $(0.176)$ & $(0.177)$ \\
\hline Tax Burden t- & -4.460 & -3.686 \\
1 & $(0.790)$ & $(0.790)$ \\
\hline Unrealized & -0.212 & -0.228 \\
Gains t-1 & $(0.073)$ & $(0.073)$ \\
\hline Inflow t-1 & 0.183 & 0.185 \\
& $(0.027)$ & $(0.028)$ \\
\hline Load Dummy & -0.567 & -0.661 \\
& $(1.218)$ & $(1.212)$ \\
\hline 8< Age <=16 & -6.234 & -6.295 \\
& $(2.116)$ & $(2.109)$ \\
\hline 16<Age & -7.109 & -7.281 \\
& $(2.218)$ & $(2.224)$ \\
\hline Log Fund Size & -1.786 & -1.731 \\
t-1 & $(0.415)$ & $(0.411)$ \\
\hline Expense Ratio & -2.538 & -2.384 \\
t-1 & $(1.740)$ & $(1.727)$ \\
\hline Turnover & -1.708 & -1.500 \\
Ratio t-1 & $(1.480)$ & $(1.531)$ \\
\hline R2 & 0.391 & 0.390 \\
\hline N & 3400 & 3400 \\
\hline
\end{tabular}

Note. All regressions include year and fund objective dummy variables. Standard errors, in parentheses, are corrected for clustering. 
Table 13: Net Inflow Regressions Using Different Tax Burden Measures Weighted by Fund Net Assets

\begin{tabular}{|l|l|l|}
\hline $\begin{array}{l}\text { Independent } \\
\text { Variable }\end{array}$ & $\begin{array}{l}\text { Tax Measure Assumes 10\% } \\
\text { Tax Rate on Undistributed } \\
\text { Gains }\end{array}$ & $\begin{array}{l}\text { Tax Measure Assumes 0\% } \\
\text { Tax Rate on Undistributed } \\
\text { Gains }\end{array}$ \\
\hline Relative & 1.899 & 1.869 \\
Return t-1 & $(0.159)$ & $(0.115)$ \\
\hline Tax Burden t- & -3.792 & -2.276 \\
1 & $(0.792)$ & $(0.479)$ \\
\hline Unrealized & -0.241 & -0.237 \\
Gains t-1 & $(0.064)$ & $(0.064)$ \\
\hline Inflow t-1 & 0.153 & 0.153 \\
& $(0.022)$ & $(0.022)$ \\
\hline Load Dummy & 2.284 & 2.250 \\
& $(1.216)$ & $(1.213)$ \\
\hline 8< Age <=16 & -6.319 & -6.330 \\
& $(1.983)$ & $(1.978)$ \\
\hline 16< Age & -6.510 & -6.514 \\
& $(2.027)$ & $(2.022)$ \\
\hline Log Fund Size & -3.254 & -3.251 \\
t-1 & $(0.553)$ & $(0.553)$ \\
\hline Expense Ratio & -2.892 & -2.766 \\
t-1 & $(1.608)$ & $(1.605)$ \\
\hline Turnover & -1.863 & -1.780 \\
Ratio t-1 & $(1.224)$ & $(1.247)$ \\
\hline R2 & 0.430 & 0.430 \\
\hline N & 4591 & 4591 \\
\hline Note. All rg & & \\
\hline
\end{tabular}

Note. All regressions include year and fund objective dummy variables. Standard errors, in parentheses, are corrected for clustering. 
Table 14: Regressions with Additional Controls, Institutional Funds Linear Regressions, Weighted by Fund Net Assets

\begin{tabular}{|c|c|c|c|c|c|}
\hline Variable & Mean & Model 1 & Model 2 & Model 3 & Model 4 \\
\hline $\begin{array}{l}\text { Pretax Return } \\
\mathrm{t}-1\end{array}$ & & $\begin{array}{l}2.069 \\
(0.454)\end{array}$ & $\begin{array}{l}3.024 \\
(0.493)\end{array}$ & $\begin{array}{l}3.005 \\
(0.492)\end{array}$ & $\begin{array}{l}2.742 \\
(0.488)\end{array}$ \\
\hline Tax Burden t-1 & & & $\begin{array}{l}-7.896 \\
(1.737) \\
\end{array}$ & $\begin{array}{l}-7.219 \\
(1.706)\end{array}$ & $\begin{array}{l}-5.967 \\
(1.655)\end{array}$ \\
\hline $\begin{array}{l}\text { Unrealized } \\
\text { Capital Gain } \\
\text { /Asset Value }\end{array}$ & & & & $\begin{array}{l}-0.185 \\
(0.129)\end{array}$ & $\begin{array}{l}-0.057 \\
(0.121)\end{array}$ \\
\hline Lagged Inflow & 25.705 & & & & $\begin{array}{l}0.079 \\
(0.022)\end{array}$ \\
\hline $8<$ Age $<=16$ & 0.305 & $\begin{array}{l}-4.373 \\
(4.295)\end{array}$ & $\begin{array}{l}-3.069 \\
(3.875)\end{array}$ & $\begin{array}{l}-2.599 \\
(3.821)\end{array}$ & $\begin{array}{l}-1.569 \\
(3.632)\end{array}$ \\
\hline $16<$ Age & 0.046 & $\begin{array}{l}-11.043 \\
(4.571)\end{array}$ & $\begin{array}{l}-8.272 \\
(3.252)\end{array}$ & $\begin{array}{l}-6.713 \\
(3.063) \\
\end{array}$ & $\begin{array}{l}-5.000 \\
(3.157)\end{array}$ \\
\hline Large Blend & 0.466 & $\begin{array}{l}7.620 \\
(6.595) \\
\end{array}$ & $\begin{array}{l}3.118 \\
(5.863) \\
\end{array}$ & $\begin{array}{l}3.460 \\
(5.809)\end{array}$ & $\begin{array}{l}3.763 \\
(5.575)\end{array}$ \\
\hline Large Growth & 0.069 & $\begin{array}{l}21.580 \\
(9.265)\end{array}$ & $\begin{array}{l}15.838 \\
(8.767)\end{array}$ & $\begin{array}{l}17.008 \\
(8.584)\end{array}$ & $\begin{array}{l}16.610 \\
(8.189)\end{array}$ \\
\hline $\begin{array}{l}\text { Mid-Cap } \\
\text { Value }\end{array}$ & 0.077 & $\begin{array}{l}-5.792 \\
(5.599)\end{array}$ & $\begin{array}{l}-5.831 \\
(5.208)\end{array}$ & $\begin{array}{l}-5.625 \\
(5.159)\end{array}$ & $\begin{array}{l}-5.229 \\
(5.477)\end{array}$ \\
\hline $\begin{array}{l}\text { Mid-Cap } \\
\text { Blend }\end{array}$ & 0.029 & $\begin{array}{l}18.651 \\
(8.423)\end{array}$ & $\begin{array}{l}12.266 \\
(7.332) \\
\end{array}$ & $\begin{array}{l}13.816 \\
(7.126)\end{array}$ & $\begin{array}{l}13.643 \\
(6.625)\end{array}$ \\
\hline $\begin{array}{l}\text { Mid-Cap } \\
\text { Growth }\end{array}$ & $0 . \overline{043}$ & $\begin{array}{l}9.161 \\
(11.062)\end{array}$ & $\begin{array}{l}5.141 \\
(10.577)\end{array}$ & $\begin{array}{l}6.626 \\
(10.223)\end{array}$ & $\begin{array}{l}5.956 \\
(10.035)\end{array}$ \\
\hline Small Value & 0.065 & $\begin{array}{l}6.599 \\
(6.439) \\
\end{array}$ & $\begin{array}{l}4.072 \\
(5.613)\end{array}$ & $\begin{array}{l}4.428 \\
(5.626)\end{array}$ & $\begin{array}{l}5.677 \\
(5.656) \\
\end{array}$ \\
\hline $\begin{array}{l}\text { Small } \\
\text { Blend }\end{array}$ & 0.031 & $\begin{array}{l}7.892 \\
(7.598)\end{array}$ & $\begin{array}{l}4.215 \\
(7.412)\end{array}$ & $\begin{array}{l}5.122 \\
(7.299)\end{array}$ & $\begin{array}{l}4.721 \\
(7.244)\end{array}$ \\
\hline Small Growth & 0.030 & $\begin{array}{l}24.598 \\
(11.072)\end{array}$ & $\begin{array}{l}19.796 \\
(9.342) \\
\end{array}$ & $\begin{array}{l}21.693 \\
(9.154) \\
\end{array}$ & $\begin{array}{l}21.652 \\
(8.979)\end{array}$ \\
\hline $\begin{array}{l}\text { Log Fund Size } \\
\mathrm{t}-1\end{array}$ & 6.855 & $\begin{array}{l}-3.527 \\
(1.224) \\
\end{array}$ & $\begin{array}{l}-4.381 \\
(1.126)\end{array}$ & $\begin{array}{l}-4.243 \\
(1.118)\end{array}$ & $\begin{array}{l}-4.406 \\
(1.080)\end{array}$ \\
\hline $\begin{array}{l}\text { Expense Ratio } \\
t-1\end{array}$ & $0 . \overline{650}$ & $\begin{array}{l}-8.437 \\
(6.571)\end{array}$ & $\begin{array}{l}-8.656 \\
(5.977)\end{array}$ & $\begin{array}{l}-8.352 \\
(5.841)\end{array}$ & $\begin{array}{l}-10.112 \\
(5.482)\end{array}$ \\
\hline $\begin{array}{l}\text { Turnover } \\
\text { Ratio t-1 }\end{array}$ & 0.505 & $\begin{array}{l}-4.593 \\
(3.518)\end{array}$ & $\begin{array}{l}0.574 \\
(3.193)\end{array}$ & $\begin{array}{l}-1.172 \\
(3.644)\end{array}$ & $\begin{array}{l}-0.396 \\
(3.481)\end{array}$ \\
\hline Load Dummy & 0.000 & $\begin{array}{l}-2.228 \\
(15.643)\end{array}$ & $\begin{array}{l}-16.233 \\
(17.053)\end{array}$ & $\begin{array}{l}-18.447 \\
(17.758)\end{array}$ & $\begin{array}{l}-12.678 \\
(15.596)\end{array}$ \\
\hline $\begin{array}{l}\text { Median Market } \\
\text { Cap }\end{array}$ & 22.131 & $\begin{array}{l}0.072 \\
(0.216)\end{array}$ & $\begin{array}{l}0.039 \\
(0.202)\end{array}$ & $\begin{array}{l}0.026 \\
(0.203)\end{array}$ & $\begin{array}{l}0.044 \\
(0.200)\end{array}$ \\
\hline $\begin{array}{l}\text { Price/Book } \\
\text { Ratio }\end{array}$ & 5.348 & $\begin{array}{l}-4.015 \\
(2.605)\end{array}$ & $\begin{array}{l}-3.445 \\
(2.470)\end{array}$ & $\begin{array}{l}-3.166 \\
(2.531)\end{array}$ & $\begin{array}{l}-3.078 \\
(2.527)\end{array}$ \\
\hline $\begin{array}{l}\text { Morningstar } \\
\text { Rating }\end{array}$ & $3 . \overline{742}$ & $\begin{array}{l}1.770 \\
(2.430)\end{array}$ & $\begin{array}{l}1.142 \\
(2.297)\end{array}$ & $\begin{array}{l}1.151 \\
(2.278)\end{array}$ & $\begin{array}{l}1.167 \\
(2.217)\end{array}$ \\
\hline R2 & & 0.158 & 0.187 & 0.189 & 0.430 \\
\hline $\mathrm{N}$ & & 751 & 751 & 751 & 751 \\
\hline
\end{tabular}

Note. Estimates based on sample of institutional funds. All regressions include year dummies. Standard errors, shown in parentheses, are corrected for clustering. 
Table 15: Summary Measures of Gross Fund Flows, 200 Largest Funds at Previous Year-end

\begin{tabular}{|l|r|l|l|l|l|l|l|}
\hline \multirow{2}{*}{ Year } & \multirow{2}{*}{$\mathrm{N}$} & \multicolumn{2}{|l|}{ Net Flow } & \multicolumn{2}{l|}{ Gross Inflow } & \multicolumn{2}{l|}{ Gross Redemptions } \\
\cline { 3 - 8 } & & Unweighted & Weighted & Unweighted & Weighted & Unweighted & Weighted \\
\hline 1994 & 137 & 3.3 & 5.9 & 31.6 & 31.1 & 28.4 & 25.2 \\
\hline 1995 & 159 & 9.4 & 14.0 & 38.6 & 39.5 & 29.2 & 25.5 \\
\hline 1996 & 156 & 4.2 & 8.9 & 34.7 & 35.8 & 30.6 & 26.9 \\
\hline 1997 & 167 & 5.4 & 7.2 & 37.1 & 34.2 & 31.7 & 27.0 \\
\hline 1998 & 67 & 11.1 & 13.4 & 45.3 & 40.3 & 34.2 & 26.8 \\
\hline $1994-98$ & 686 & 6.2 & 9.6 & 36.6 & 36.1 & 30.5 & 26.5 \\
\hline
\end{tabular}

Note. Sample includes 686 fund-years of data on large domestic equity funds over the period 1994-1998. 
Table 16: After-Tax Retums and Gross Inflows and Outflows, 200 Largest Funds at Previous Year-end

Panel A: Unweighted Results

\begin{tabular}{|l|l|l|l|}
\hline Explanatory Variable: & Net Inflow & Gross Inflow & Gross Outflow \\
\hline Excluding Capital Gain Overhang & 41.974 & 74.724 & 32.749 \\
& $(6.383)$ & $(9.137)$ & $(4.921)$ \\
\hline Constant & 2.285 & 2.103 & -0.182 \\
& $(0.263)$ & $(0.346)$ & $(0.200)$ \\
\hline Pretax Retum & -5.784 & -5.756 & 0.028 \\
& $(1.296)$ & $(2.033)$ & $(1.346)$ \\
\hline Tax Burden & 0.215 & 0.117 & 0.012 \\
& \multicolumn{3}{|l|}{} \\
\hline R2 & 50.211 & 89.358 & 39.147 \\
\hline Including Capital Gain Overhang & $(10.660)$ & $(5.488)$ \\
\hline Constant & $(7.621)$ & 2.162 & -0.156 \\
& 2.318 & $(0.346)$ & $(0.198)$ \\
\hline Pretax Return & $(0.266)$ & -4.825 & 0.435 \\
& -5.260 & $(2.024)$ & $(1.389)$ \\
\hline Tax Burden & $(1.260)$ & -0.537 & -0.235 \\
& -0.302 & $0.166)$ & $(0.109)$ \\
\hline Unrealized Capital Gains & $(0.093)$ & 0.147 & 0.028 \\
As Share of Fund Value & 0.231 & \\
\hline R2 & \multicolumn{2}{|l|}{} \\
\hline
\end{tabular}

Panel B: Results Weighting by Fund Assets

Without Capital Gain Overhang

\begin{tabular}{|l|l|l|l|}
\hline Constant & 9.766 & 32.613 & 22.847 \\
& $(1.772)$ & $(2.916)$ & $(2.039)$ \\
\hline Pretax Retum & 2.142 & 1.958 & -0.183 \\
& $(0.260)$ & $(0.275)$ & $(0.181)$ \\
\hline Tax Burden & -5.816 & -7.565 & -1.749 \\
& $(1.578)$ & $(2.311)$ & $(1.622)$ \\
\hline Adjusted R2 & 0.242 & 0.123 & 0.028 \\
\hline \multicolumn{2}{|l|}{ Including Capital Gain Overhang } & 45.208 & \\
\hline Constant & 15.522 & $(3.435)$ & 29.686 \\
& $(2.389)$ & 2.156 & $(2.477)$ \\
\hline Pretax Retum & 2.232 & $(0.270)$ & -0.076 \\
& $(0.258)$ & -6.571 & $(0.183)$ \\
\hline Tax Burden & -5.362 & $(2.239)$ & -1.209 \\
& $(1.509)$ & -0.791 & $(1.651)$ \\
\hline Unrealized Capital Gains & -0.361 & $(0.167)$ & -0.429 \\
As Share of Fund Value & $(0.097)$ & 0.197 & $(0.111)$ \\
\hline Adjusted R2 & 0.267 & 0.085 \\
\hline
\end{tabular}

Note. Sample includes 686 fund-years of data on large domestic equity funds over the period 1994-1998.

Retums are measured relative to $\mathrm{S} \& \mathrm{P} 500$ retum. 